Review

\title{
Wnt Signaling Pathway Is among the Drivers of Liver Metastasis
}

\author{
Ivana Samaržija ${ }^{1,2}$ (D)
}

check for

updates

Citation: Samaržija, I. Wnt Signaling Pathway Is among the Drivers of Liver Metastasis. Livers 2021, 1 , 180-200. https://doi.org/10.3390/ livers1040015

Academic Editor: Gian Luca Grazi

Received: 28 August 2021

Accepted: 27 September 2021

Published: 4 October 2021

Publisher's Note: MDPI stays neutral with regard to jurisdictional claims in published maps and institutional affiliations.

Copyright: (C) 2021 by the author. Licensee MDPI, Basel, Switzerland. This article is an open access article distributed under the terms and conditions of the Creative Commons Attribution (CC BY) license (https:/ / creativecommons.org/licenses/by/ $4.0 /)$.
1 Laboratory for Epigenomics, Division of Molecular Medicine, Ruđer Bošković Institute, 10000 Zagreb, Croatia; Ivana.Samarzija@irb.hr

2 Laboratory for Cell Biology and Signaling, Division of Molecular Biology, Ruđer Bošković Institute, 10000 Zagreb, Croatia

\begin{abstract}
Liver metastasis, originating either from a primary liver or other cancer types, represent a large cancer-related burden. Therefore, studies that add to better understanding of its molecular basis are needed. Herein, the role of the Wnt signaling pathway in liver metastasis is outlined. Its role in hepatocellular carcinoma (HCC) epithelial-mesenchymal transition (EMT), motility, migration, metastasis formation, and other steps of the metastatic cascade are presented. Additionally, the roles of the Wnt signaling pathway in the liver metastasis formation of colorectal, breast, gastric, lung, melanoma, pancreatic, and prostate cancer are explored. The special emphasis is given to the role of the Wnt signaling pathway in the communication between the many of the components of the primary and secondary cancer microenvironment that contribute to the metastatic outgrowth in the liver. The data presented herein are a review of the most recent publications and advances in the field that add to the idea that the Wnt pathway is among the drivers of liver metastasis and that its targeting could potentially relieve liver metastasis-related complications.
\end{abstract}

Keywords: Wnt signaling pathway; liver metastasis; hepatocellular carcinoma; colorectal cancer; breast cancer; gastric cancer; lung cancer; melanoma; pancreatic cancer; prostate cancer

\section{Introduction}

Malignant primary and secondary liver cancers account for the vast part of cancerrelated negative burdens. The most common primary liver cancer is hepatocellular carcinoma (HCC), which is among the top cancers according to the incidence and mortality. It represents approximately $90 \%$ of all liver cancers and has an incidence of 850,000 new cases per year [1]. HCC usually occurs in the setting of chronic liver inflammation and is often linked to chronic viral hepatitis infection (hepatitis B or C) or exposure to toxins (e.g., alcohol). Another type of common liver cancer is intrahepatic cholangiocarcinoma (ICC). ICC is an aggressive epithelial malignancy of the bile ducts within the liver that is often locally advanced to metastatic disease and has an extremely poor prognosis. The recurrence of liver cancer after hepatic resection remains a major complication with no adjuvant therapies able to prevent it. Recurrence rates are as high as $70 \%$ at 5 years and are divided into either early ( $<2$ years) or late ( $>2$ years) [2]. Recurrence that takes place earlier is usually due to micro-metastases that remained and progressed after resection, while the late onset recurrence results from de novo tumors arising in a microenvironment that is primed for their development. Although metastasis originating from HCC and ICC can be detected in other organs, the most common site of metastasis of the primary HCC and ICC is the liver itself, which contributes to the above-mentioned recurrence scenarios.

Another frequent cancer-related liver malignancy includes metastasis from the colorectal cancer (CRC) accounting for the most common primary cancer that metastasizes to the liver. The percentage of CRC that metastasize to the liver is 30-50\% [3]. Liver metastasis is a leading cause of death for CRC patients and, given the fact that CRC is among the top five cancers by incidence and mortality [4], it is evident that this type of disease progression represents large cancer-related burden. Other common primary cancers that metastasize to 
the liver include lung, melanoma, breast, pancreatic, and gastric cancer, each with high incidences for this type of disease progression [3].

It is evident from these introductory lines that liver metastasis, originating either from primary liver or other cancer types (Figure 1), represents a significant cancer-related complication. Therefore, efforts are being made in understanding their biology and finding the targets for the effective treatment. In this paper, the role of the Wnt signaling pathway as a driving force in liver metastasis originating from primary liver cancer and from other cancer types is explored.

A)

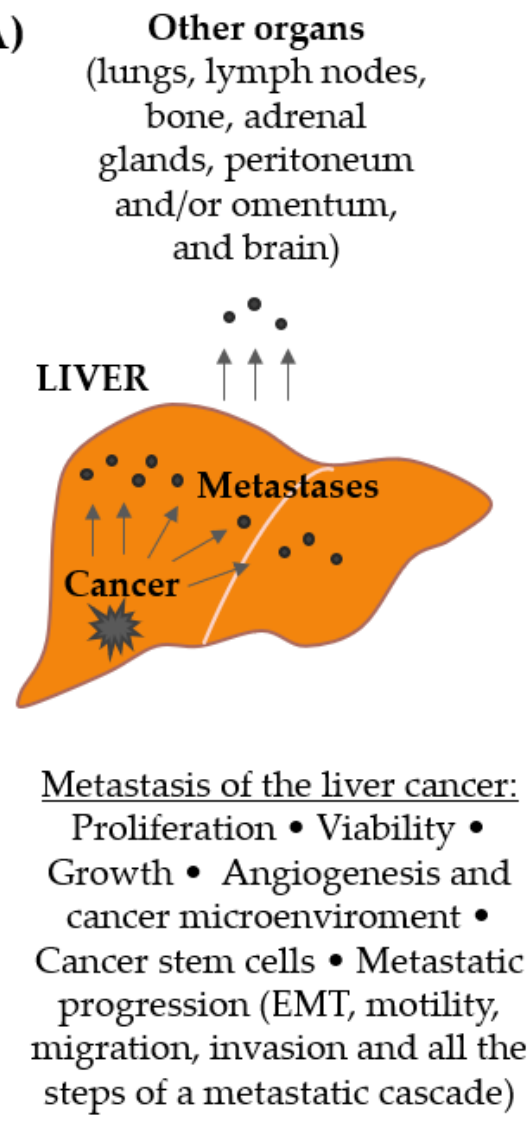

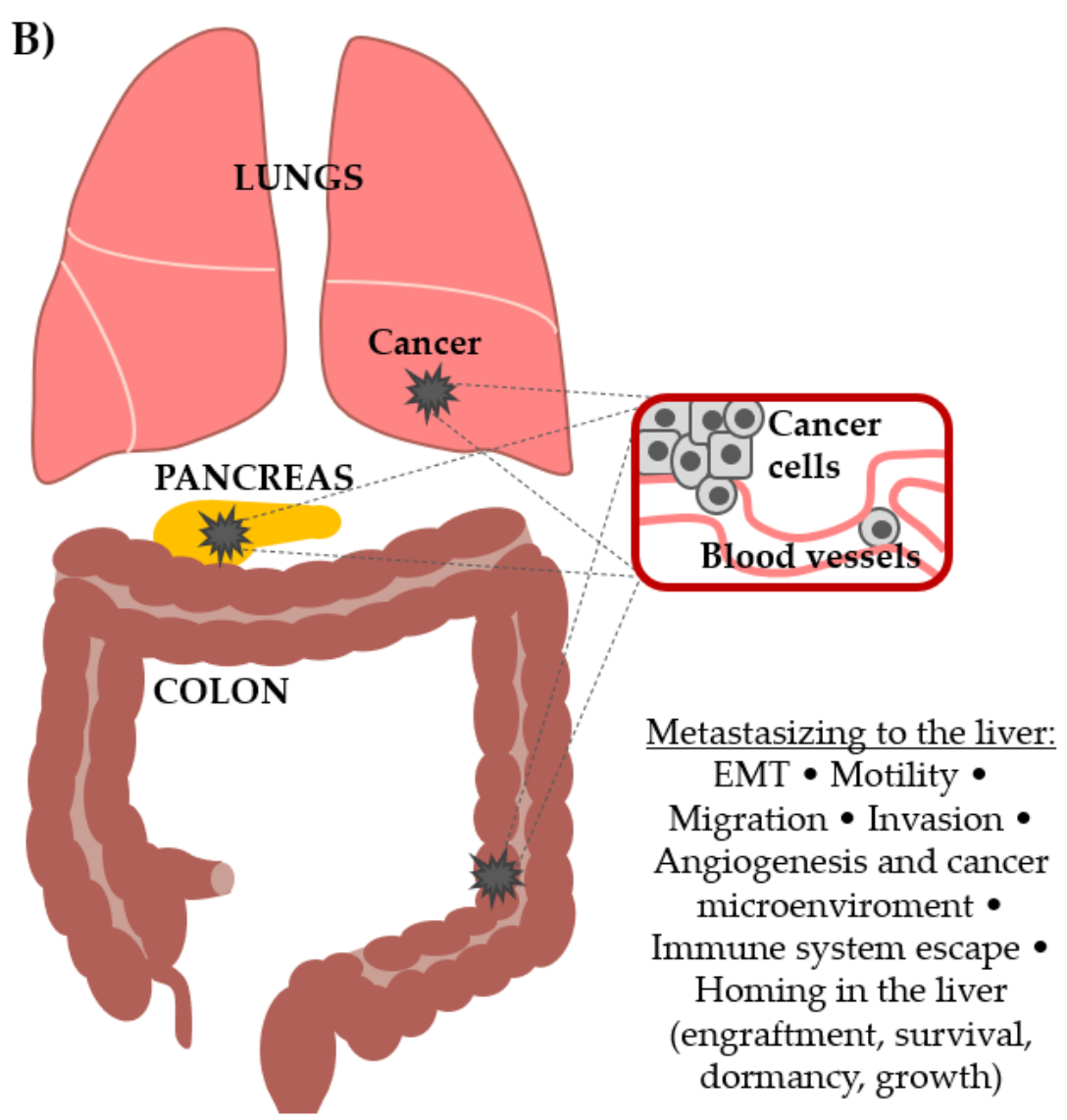

Figure 1. Involvement of the Wnt signaling pathway in (A) the progression and metastasis formation by primary liver cancer and in (B) the formation of secondary cancers in the liver (metastasis from other primary tumors, most commonly colorectal, pancreatic, melanoma, lung, breast, gastric, and prostate). Different processes that lead to metastatic outgrowth in both scenarios are delineated.

\section{Wnt Signaling Pathways}

Wnt signaling is initiated by Wnt-secreted glycoproteins that bind to the seven transmembrane spanning domains containing receptors from the Frizzled family. There are 19 Wnt and 10 Frizzled genes in humans. Specificity of the Wnt signaling is possibly achieved through cell-specific expression of Frizzled receptors, or additionally, through the association of Frizzled receptors with different co-receptors. Several different pathways downstream of Wnt binding to Frizzled could be initiated, like outlined below.

\section{1. 'Canonical' Wnt Signaling Pathway}

Among the Wnt signaling pathways, Wnt/ $\beta$-catenin is the best studied and, therefore, denoted as the Wnt 'canonical' pathway. In the absence of Wnt 'canonical' pathway activation, cytoplasmic $\beta$-catenin is destined for a destruction in a so-called $\beta$-catenin destruction complex. This complex includes axin, adenomatous polyposis coli (APC), and 
diversin. In this complex, $\beta$-catenin becomes phosphorylated by the serine/threonine kinases casein kinase 1 (CK1) and glycogen synthase kinase 3 beta (GSK3 $\beta$ ). Subsequently, $\beta$-catenin is targeted for ubiquitination by the beta-transducin repeat-containing protein $(\beta-\operatorname{TrCP})$ and is then degraded by the proteasome. Activation of the Wnt/ $\beta$-catenin pathway results in the recruitment of a cytoplasmic mediator Dishevelled (Dvl) which leads to the stabilization of a transcription co-factor $\beta$-catenin which accumulates in the cytoplasm and enters the nucleus. In the nucleus, $\beta$-catenin acts as a co-activator of the T-cell factor/lymphoid enhancer factor-1 (TCF/LEF) transcription factors and contributes to the expression of different target genes. Among other genes with similar function, B-cell CLL/lymphoma 9 protein (BCL9) has been shown to promote $\beta$-catenin's transcriptional activity. The common Wnt/ $\beta$-catenin target genes include c-Myc, cyclin D1 (CCND1), c-Jun, Axin-2, etc. In the absence of a Wnt signal, TCF/LEF family members interact with transcriptional inhibitors which serve to repress Wnt signaling. The Wnt/ $\beta$-catenin pathway is essential during development, cell proliferation, differentiation, migration, and survival and is frequently deregulated in different pathological states [5].

\section{2. 'Non-Canonical' Wht Signaling Pathways}

Several 'non-canonical' Wnt pathways have also been described. Among them, the Wnt/planar cell polarity (PCP) and Wnt/calcium pathways are the best understood. Common theme for both pathways is Dvl activation upon ligand binding to the receptor, but these pathways diverge further downstream. The PCP pathway is characterized by the activation of the Rho/Rac GTPases. When this pathway is activated, Wnt binding to Frizzled receptors mediates asymmetric cytoskeletal organization and the polarization of cells by influencing the actin cytoskeleton [6]. The Wnt/calcium pathway leads to the release of intracellular calcium and activates calcium-activated protein kinase C (PKC) and calcium/calmodulin-dependent protein kinase II (CamKII). Frizzled co-receptors involved in this pathway include Knypek and receptor tyrosine kinase like orphan receptor 2 (Ror2). The Wnt/calcium pathway is important for cell adhesion and cell movements during gastrulation [7].

For easier comprehension, Wnt signaling pathways are usually described as individual pathways, but reported crosstalk and shared components between the Wnt signaling branches suggest that Wnts act through a complex intracellular signaling network [8].

\subsection{Proteins That Modulate Wnt Signaling Pathways}

Some of the proteins that influence Wnt signaling include Wntless (Wls). Wls is a highly conserved transmembrane protein located in compartments of the secretory pathway that shuttles palmitoylated Wnt proteins from the endoplasmic reticulum to the plasma membrane and acts as a Wnt cargo receptor [9].

Wnt antagonists are divided into the secreted Frizzled related proteins (sFRP class) and the Dickkopf (DKK) class. sFRP class includes the sFRP family (sFRP1-5), Wnt inhibitory factor-1 (WIF-1), and Cerberus. These antagonists act by binding directly to Wnt, disturbing their ability to bind to the receptor. Members of the Dickkopf class (DKK1-4) inhibit Wnt signaling by binding to co-receptor LDL receptor related protein (LRP) 5/LRP6 of the Wnt/ $\beta$-catenin pathway. Therefore, while sFRP class of the antagonists may inhibit both canonical and noncanonical Wnt signaling pathways, those of the DKK class specifically inhibit Wnt/ $\beta$-catenin pathway [10].

\section{Wnt Signaling Pathway Drives Hepatocellular Carcinoma Metastasis}

The role of Wnt signaling pathway in HCC primary growth and treatment is well described and has been reviewed elsewhere [11,12]. Briefly, most liver tumors have mutations in genes encoding key components of the Wnt/ $\beta$-catenin signaling pathway. This pathway has been suggested to have an important role in the pathogenesis of HCC and especially in the transition from chronic liver diseases, including viral hepatitis, to hepatocellular adenomas and further, from adenomas to HCC [12]. $\beta$-catenin activation has also been 
linked to immunotherapy resistance in HCC [13]. For these reasons, the Wnt/ $\beta$-catenin pathway has been suggested to be a mechanism by which cells evade anti-tumor drugs and the immune system [14]. Consequently, the components of the Wnt pathway are considered to be the targets in HCC treatment $[15,16]$.

This chapter explores another important role for Wnt signaling pathway in HCC and that is in their regional (intrahepatic) and systemic (other sites) metastatic progression.

\subsection{Aberrant Expression of Wnt Signaling Pathway Components Correlates with the Ability of Liver Cancers to Metastasize}

Early studies have noted that the expression of the genes that are implicated in the Wnt signaling pathway correlates with metastatic abilities of HCC. For example, nuclear accumulation combined with cytoplasmic accumulation of $\beta$-catenin tended to be associated with metastasis and vascular invasion in HCC [17]. High Wnt3a expression in HCC was related to poorly differentiated grade, liver cirrhosis, hepatitis B virus infection, higher tumor-node metastasis stage, and 5-year survival rate [18]. In addition, overexpression of Dvl2 correlated with histological grade, metastasis, and vein invasion in patients with HCC, and the knockdown of Dvl2 reduced cell migration and invasion in HepG2 cells. [19]. Further to this, the TCF4 gene expression was closely associated with intrahepatic metastasis of HCC [20] and BCL9 expression was significantly associated with microvascular invasion and intrahepatic metastasis [21]. Wls is highly expressed in advanced-stage ICC. The intensity of Wls expression was positively associated with tumor stage, tumor-nodemetastasis stage, and lymphatic invasion in ICC [22]. These studies indicate that metastatic progression of HCC and ICC include higher expression of some of the components that positively regulate the Wnt signaling pathway.

3.2. Mechanisms of Action of the Wnt Signaling Pathway in Liver Cancers Metastasis Process: The Roles in EMT, Migration, Invasion, and Metastasis Formation

Mechanistically, one of the first steps in metastatic cancer progression is epithelialmesenchymal transition (EMT) by which epithelial cells gain migratory and invasive properties and become mesenchymal cells. It has been shown that crosstalk between $\beta$-catenin and Snail induces EMT in HCC [23]. Additionally, Wnt/ $\beta$-catenin signaling enhances hypoxia-induced EMT in HCC by increasing the EMT-associated activity of HIF$1 \alpha$ [24]. Hypoxia, on the other hand, activates Wnt/ $\beta$-catenin signaling by inducing the expression of BCL9 in human HCC [25]. The importance of the Wnt pathway activation for EMT in HCC cells was further confirmed by the study that showed that TGF $\beta$ signaling in HCC EMT includes joint activation of the Sonic hedgehog and Wnt signaling pathways [26]. These studies have described that Wnt pathway is an important part of the network of signaling pathways that induce complex EMT process. To delineate components of the Wnt pathway that are involved in HCC EMT, it was shown, for example, by pharmacologic and genetic interventions, that Fzd2 expression induces EMT and enhances cell migration and invasiveness through a previously unknown, non-canonical pathway that includes Fyn and Stat3 [27,28].

Further mechanistic insights into Wnt pathways' role in HCC metastasis came from the study that has shown that deletion of Wnt3a inhibits migration and invasion by downregulating matrix metalloproteinases (MMP) -2/-7/-9 expression via the MAPK pathway [29]. MMPs stimulate the degradation of extracellular matrix components and promote the migration of cancer cells into the surrounding tissue. The involvement of miRNAs downstream of Wnt signaling has been shown in the work that described that the $\beta$-catenin/TCF-4-LINC01278-miR-1258-Smad2/3 axis promotes HCC lung metastasis [30]. Taken together, these publications are delineating the events downstream of Wnt signaling pathway activation that induce HCC metastasis formation.

While the above studies interrogated mainly the role of Wnt/ $\beta$-catenin pathway, a recent study has shown that downregulation of VANGL1 inhibits cellular invasion and only slightly affects motility in HCC cells. The VANGL1 protein is one of the core components of the Wnt/PCP pathway and this work suggests that the Wnt/PCP pathway may play 
a role in progression of HCC affecting cellular invasion but its role in cell motility is less prominent [31].

Since the discovery of the positive role of Wnt signaling in HCC metastasis formation, several studies have explored the expression and the ability of re-introduction of its antagonists into HCC cell lines and a consecutive role in metastasis formation. In this way, it has been shown that reconstitution of Wnt pathway antagonist, sFRP-1, suppresses tumor growth, angiogenesis, and lung metastasis in HCC cell line MHCC97-H xenografts [32]. Furthermore, the expression of another antagonist, WIF1, in HCC cell lines negatively correlated with their metastatic potential. The up-regulation of WIF1 expression inhibited the invasion of HepG2 and SMMC-7721 HCC cell lines possibly through the Wnt/ $\beta$-catenin signaling pathway [33]. Although DKK1 is a well-described antagonist that suppresses $W n t / \beta$-catenin signaling, studies have shown that it might promote HCC cell migration and invasion through the $\beta$-catenin/MMP7 signaling pathway [34-36]. However, DKK4 suppresses cell invasion in human hepatoma cells [37]. These studies remind of the complexity of the Wnt signaling pathways and multitude of players that are involved and whose specificity of action most probably depends on a cell type, as seen with DKK1 [38].

\section{Proteins That Converge to Wnt Signaling Pathway to Influence Liver Cancer} Metastasis Formation

The studies mentioned above clearly indicate a role for Wnt signaling in HCC metastasis formation. Numerous other studies that analyze the roles of single proteins in HCC metastasis formation have shown that many of these proteins converge to the Wnt signaling pathway. Such a network of proteins is briefly outlined in the Table 1, establishing firmly the role of the Wnt pathway in HCC EMT, motility, migration, invasion, and metastasis formation. Additionally, the involvement of several miRNAs and lncRNAs into signaling that leads to Wnt pathway activation has been shown. Those are either downstream of the Wnt signaling pathway like miR-25 [39] and miR-1258 [30] or converge to its activation or inhibition like, for example, miR-885-5p [40], miR-148b [41], miR-429 [42], miR-197 [43], miR-212 [44], miR-3194-3p [45], and miR-186 [46].

Table 1. Proteins that converge to the Wnt signaling pathway and in that way influence epithelial-mesenchymal transition (EMT), motility, migration, invasion, and metastasis of hepatocellular carcinoma (HCC). The publications are listed in chronological order.

\begin{tabular}{|c|c|c|c|}
\hline Protein & Mechanism & Effect & Ref. \\
\hline HGF & $\begin{array}{c}\text { Activates Wnt pathway by transcriptional } \\
\text { activation of LEF1 }\end{array}$ & Facilitates in vitro tumor migration and invasion & [47] \\
\hline CTHRC1 & Activates the PCP pathway of Wnt signaling & $\begin{array}{c}\text { Promotes in vitro tumor migration and invasion } \\
\text { and cell-matrix adhesion }\end{array}$ & [48] \\
\hline CAV1 & $\begin{array}{c}\text { Induces Wnt } / \beta \text {-catenin pathway through nuclear } \\
\text { accumulation of } \beta \text {-catenin }\end{array}$ & $\begin{array}{c}\text { Enhances EMT, invasiveness, and lung } \\
\text { metastasis in vitro and in vivo }\end{array}$ & [49] \\
\hline CLDN3 & $\begin{array}{l}\text { Inactivates the Wnt/ } \beta \text {-catenin-EMT axis through } \\
\text { downregulation of GSK3B, CTNNB1, SNAI2, and } \\
\text { CDH2 }\end{array}$ & $\begin{array}{l}\text { Inhibits cell motility and invasiveness in vitro } \\
\text { and in vivo }\end{array}$ & {$[50]$} \\
\hline AEG-1 & $\begin{array}{l}\text { Transcriptionally regulated by c-Myc and induces } \\
\text { c-Myc by activating the Wnt / } \beta \text {-catenin pathway } \\
\text { Promotes } \beta \text {-catenin nuclear translocation, }\end{array}$ & $\begin{array}{l}\text { Activates prosurvival and EMT-signaling } \\
\text { pathways and induces in vivo lung metastasis }\end{array}$ & [51] \\
\hline GAL1 & $\begin{array}{c}\text { TCF4/LEF1 transcriptional activity and CCND1 } \\
\text { and c-Myc expression }\end{array}$ & Triggers EMT in vitro & [52] \\
\hline TRIM37 & Activates the Wnt/ $\beta$-catenin pathway & $\begin{array}{l}\text { Promotes in vitro and in vivo cell migration and } \\
\text { metastasis by inducing EMT }\end{array}$ & [53] \\
\hline HKDC1 & $\begin{array}{c}\text { Downregulation represses } \beta \text {-catenin and c-Myc } \\
\text { expression }\end{array}$ & Associated with aggressive phenotype & [54] \\
\hline
\end{tabular}


Table 1. Cont.

\begin{tabular}{|c|c|c|c|}
\hline Protein & Mechanism & Effect & Ref. \\
\hline FRAT1 & $\begin{array}{c}\text { Knockdown suppresses Wnt/ } \beta \text {-catenin pathway } \\
\text { by partially suppressing the expression levels of } \\
\beta \text {-catenin, CCND1, and c-Myc }\end{array}$ & $\begin{array}{l}\text { Knockdown inhibits in vitro hypoxia-induced } \\
\text { EMT, migration, and invasion }\end{array}$ & [55] \\
\hline NTR1 & $\begin{array}{l}\text { NTS/NTR1 co-expression correlates with the } \\
\text { activation of the Wnt/ } \beta \text {-catenin signaling pathway }\end{array}$ & $\begin{array}{l}\text { NTS/NTR1 co-expression enhances EMT, } \\
\text { invasion, and in vivo metastasis formation }\end{array}$ & [56] \\
\hline CTNND1 & $\begin{array}{l}\text { Acts, at least in part, by indirectly enhancing } \\
\text { Wnt } / \beta \text {-catenin signaling }\end{array}$ & $\begin{array}{l}\text { Promotes in vitro migration, invasion, and } \\
\text { in vivo metastasis formation }\end{array}$ & [57] \\
\hline PRC1 & $\begin{array}{c}\text { Inhibits APC stability, and promotes } \beta \text {-catenin } \\
\text { release from the APC complex }\end{array}$ & Promotes in vitro migration and invasion & [58] \\
\hline CX32 & $\begin{array}{l}\text { Its inhibition enhances Snail expression through } \\
\text { activation of Wnt/ } \beta \text {-catenin signaling }\end{array}$ & $\begin{array}{l}\text { Regulates EMT, migration, and invasion in vitro } \\
\text { and inhibits tumor metastasis in vivo }\end{array}$ & [59] \\
\hline FERMT2 & $\begin{array}{c}\text { Activates Wnt } / \beta \text {-catenin signaling and increases } \\
\beta \text {-catenin expression (especially } \\
\text { non-phosphorylated form) }\end{array}$ & Promotes in vitro invasion and metastasis & {$[60]$} \\
\hline OCT4 & $\begin{array}{l}\text { Upregulates LEF1, a key component of the WNT } \\
\text { signaling pathway }\end{array}$ & Induces EMT in vitro & [61] \\
\hline DDX39 & $\begin{array}{c}\text { Activates Wnt / } \beta \text {-catenin pathway by increasing } \\
\beta \text {-catenin levels in the nucleus }\end{array}$ & $\begin{array}{c}\text { Promotes tumor growth, migration, invasion, } \\
\text { and in vivo metastasis }\end{array}$ & [62] \\
\hline PCL3 & $\begin{array}{c}\text { Inhibits } \beta \text {-catenin degradation, and activates } \\
\beta \text {-catenin/TCF signaling }\end{array}$ & $\begin{array}{c}\text { Positively regulates the migration, invasion, and } \\
\text { in vivo metastasis formation }\end{array}$ & [63] \\
\hline ITGB5 & $\begin{array}{c}\text { Directly interacts with } \beta \text {-catenin and inhibits its } \\
\text { degradation, thus leading to Wnt/ } \beta \text {-catenin } \\
\text { activity }\end{array}$ & Elevated ITGB5 facilitates in vitro cell migration & [64] \\
\hline JUB & Activates $\beta$-catenin in the nuclei & Induces in vitro EMT and migration & [65] \\
\hline LRP16 & $\begin{array}{l}\text { Its overexpression could prevent } \beta \text {-catenin from } \\
\text { entering the nucleus }\end{array}$ & $\begin{array}{l}\text { Attenuates cell migration, and invasion in vitro, } \\
\text { and metastasis in vivo }\end{array}$ & {$[66]$} \\
\hline ZIC5 & $\begin{array}{l}\text { Increases the expression of } \beta \text {-catenin and CCND1 } \\
\text { and promotes } \beta \text {-catenin to enter the nucleus }\end{array}$ & $\begin{array}{l}\text { Promotes proliferation, migration, and invasion } \\
\text { in vitro and in vivo }\end{array}$ & [67] \\
\hline SOX9 & $\begin{array}{l}\text { SOX9-AS1/miR-5590-3p/SOX9 positive feedback } \\
\text { acts through the Wnt/ } \beta \text {-catenin pathway }\end{array}$ & $\begin{array}{c}\text { Aggravates HCC progression and metastasis } \\
\text { in vitro and in vivo }\end{array}$ & [68] \\
\hline AKIP1 & $\begin{array}{l}\text { Interacts with and sustains } \beta \text {-catenin in the } \\
\text { nucleus by blocking its interaction with APC; } \\
\text { enhances phosphorylation of } \beta \text {-catenin }\end{array}$ & $\begin{array}{l}\text { Promotes invasion and increases intrahepatic } \\
\text { and lung metastasis in vivo }\end{array}$ & [69] \\
\hline FBXO17 & $\begin{array}{c}\text { Its silencing might function through } \\
\text { downregulating the expression of proteins in } \\
\text { Wnt } / \beta \text {-catenin pathway }\end{array}$ & $\begin{array}{l}\text { In vitro metastasis ability in the anti-FBXO17 } \\
\text { group is decreased }\end{array}$ & {$[70]$} \\
\hline FOXG1 & $\begin{array}{l}\text { Activates Wnt signaling through forming } \\
\text { TCF4/ } \beta \text {-catenin/FOXG1 complex }\end{array}$ & $\begin{array}{l}\text { Promotes EMT and aggressiveness in vitro and } \\
\text { enhances metastasis in vivo }\end{array}$ & [71] \\
\hline GATA5 & $\begin{array}{l}\text { Co-localizes with } \beta \text {-catenin in the cytoplasm, } \\
\text { preventing } \beta \text {-catenin from entering the nucleus }\end{array}$ & $\begin{array}{c}\text { Inhibits in vitro cell growth, colony formation, } \\
\text { migration, and invasion }\end{array}$ & [72] \\
\hline GRP78 & $\begin{array}{c}\text { Activates the Wnt/HOXB9 pathway by } \\
\text { chaperoning LRP6 }\end{array}$ & $\begin{array}{c}\text { Promotes in vitro and in vivo invasion and } \\
\text { metastasis }\end{array}$ & [73] \\
\hline HEG1 & $\begin{array}{l}\text { Promotes } \beta \text {-catenin expression and maintains its } \\
\text { stability, leading to its accumulation and nuclear } \\
\text { translocation }\end{array}$ & $\begin{array}{l}\text { Promotes EMT and in vitro and in vivo invasion } \\
\text { and metastasis }\end{array}$ & [74] \\
\hline NDRG3 & Promotes nuclear translocation of $\beta$-catenin & $\begin{array}{l}\text { Enhances metastasis and angiogenesis in vitro } \\
\text { and in vivo }\end{array}$ & [75] \\
\hline MSI1 & $\begin{array}{l}\text { Activates Wnt/ } \beta \text {-catenin signaling pathway } \\
\text { (downregulation reduces the expression of } \\
\text { phospho- } \beta \text {-catenin and CCND1 and elevates the } \\
\text { protein expression of DKK1 and APC) }\end{array}$ & $\begin{array}{l}\text { Affects in vitro cancer cell viability, migration, } \\
\text { and invasiveness }\end{array}$ & [76] \\
\hline p62/IMP2 & Activates Wnt $/ \beta$-catenin pathway & Promotes in vitro EMT and migration & [77] \\
\hline RICH2 & $\begin{array}{c}\text { Overexpression positively correlates with the } \\
\text { expression of WNT5a and inversely correlates } \\
\text { with } \beta \text {-catenin }\end{array}$ & $\begin{array}{l}\text { Inhibits formation of filopodia and invasion and } \\
\text { proliferation in vitro }\end{array}$ & {$[78]$} \\
\hline
\end{tabular}


Table 1. Cont.

\begin{tabular}{|c|c|c|c|}
\hline Protein & Mechanism & Effect & Ref. \\
\hline AQP9 & $\begin{array}{l}\text { Overexpression reduces the levels of DVL2, } \\
\text { GSK-3 } \beta, \text { CCND1, and } \beta \text {-catenin }\end{array}$ & $\begin{array}{c}\text { Overexpression suppresses in vitro migration, } \\
\text { invasion, and EMT }\end{array}$ & [79] \\
\hline ARHGEF11 & $\begin{array}{c}\text { Induces } \beta \text {-catenin nuclear translocation and } \\
\text { upregulates ZEB1 }\end{array}$ & Promotes EMT and migration in vitro & {$[80]$} \\
\hline GAL3 & $\begin{array}{c}\text { Activates the PI3K-Akt-GSK-3 } \beta \text { - } \beta \text {-catenin } \\
\text { signaling cascade }\end{array}$ & $\begin{array}{l}\text { Regulates in vitro angiogenesis and EMT and } \\
\text { favors tumor lung metastasis in vivo }\end{array}$ & {$[81]$} \\
\hline KIF2C & $\begin{array}{l}\text { Direct target of the Wnt / } \beta \text {-catenin pathway that } \\
\text { mediates the crosstalk between Wnt } / \beta \text {-catenin } \\
\text { and mTORC1 signaling }\end{array}$ & $\begin{array}{l}\text { Promotes migration, invasion, and metastasis } \\
\text { both in vitro and in vivo }\end{array}$ & {$[82]$} \\
\hline KIF18B & $\begin{array}{l}\text { The knockdown downregulates the expression of } \\
\text { c-Myc, CCND1, } \beta \text {-catenin, and p-GSK-3 } \beta\end{array}$ & $\begin{array}{l}\text { Knockdown might suppressproliferation, } \\
\text { migration, and invasion in vitro }\end{array}$ & {$[83]$} \\
\hline $\mathrm{MTDH}$ & $\begin{array}{c}\text { Its overexpression induces PRMT5 translocation } \\
\text { from the nucleus to the cytoplasm and } \\
\text { translocation of } \beta \text {-catenin from the cytoplasm to } \\
\text { the nucleus which upregulates WNT/ } \beta \text {-catenin } \\
\text { signaling pathway }\end{array}$ & $\begin{array}{l}\text { PRMT5 and } \beta \text {-catenin play a pivotal role in } \\
\text { MTDH-mediated HCC in vivo metastasis }\end{array}$ & {$[84]$} \\
\hline NRF1 & $\begin{array}{c}\text { Enhances ubiquitination of } \beta \text {-catenin for targeting } \\
\text { proteasomal degradation }\end{array}$ & $\begin{array}{c}\text { Promotes invasion and metastasis to the lung } \\
\text { and liver in in vivo models }\end{array}$ & {$[85]$} \\
\hline FXR & $\begin{array}{l}\text { Decreases expression of } \beta \text {-catenin target genes and } \\
\text { reduces nuclear translocation of } \beta \text {-catenin proteins } \\
\text { in vitro and in vivo }\end{array}$ & $\begin{array}{l}\text { Suppresses migration and invasion in vitro and } \\
\text { inhibits local invasion and lung metastasis } \\
\text { in vivo }\end{array}$ & {$[86]$} \\
\hline USP1 & $\begin{array}{l}\text { Its knockout impairs expression of Wnt target } \\
\text { genes }\end{array}$ & $\begin{array}{c}\text { Frequently upregulated in liver circulating } \\
\text { tumor cells and expression correlates with } \\
\text { metastasis }\end{array}$ & [87] \\
\hline ATE1 & $\begin{array}{l}\text { Accelerates degradation of } \beta \text {-catenin and inhibits } \\
\text { Wnt signaling by regulating turnover of RGS5 }\end{array}$ & $\begin{array}{l}\text { Knockdown promotes cancer growth, migration, } \\
\text { and disease progression in vitro and in vivo }\end{array}$ & [88] \\
\hline PGC $1 \alpha$ & $\begin{array}{c}\text { Inhibits Warburg effect by PPAR } \gamma \text {-dependent } \\
\text { WNT/ } \beta \text {-catenin/PDK1 axis }\end{array}$ & Suppresses in vitro and in vivo metastasis & [89] \\
\hline RAD54B & $\begin{array}{l}\text { Increases nuclear } \beta \text {-catenin and up-regulates } \\
\text { Wnt/ } \beta \text {-catenin downstream target genes (c-Myc, } \\
\text { CCND1, MMP7, CD44, VEGF, c-Jun) }\end{array}$ & $\begin{array}{l}\text { Increases in vitro cell viability and motility, and } \\
\text { in vivo intrahepatic metastasis }\end{array}$ & {$[90]$} \\
\hline ZEB1 & $\begin{array}{c}\text { Could activate the Wnt } / \beta \text {-catenin signaling } \\
\text { pathway by upregulating the protein expression } \\
\text { levels of } \beta \text {-catenin, c-Myc, and CCND1 }\end{array}$ & $\begin{array}{l}\text { Promotes in vitro cell proliferation and } \\
\text { migration and inhibits apoptosis }\end{array}$ & [91] \\
\hline
\end{tabular}

Abbreviations: HGF, hepatocyte growth factor; CTHRC1, collagen triple helix repeat containing 1; CAV1, caveolin 1; CLDN3, claudin 3; AEG-1, astrocyte elevated gene-1; GAL1, galectin-1; TRIM37, tripartite motif containing 37; HKDC1, hexokinase domain containing 1; FRAT1, frequently rearranged in advanced T-cell lymphomas 1; NTR1, neurotensin receptor 1; CTNND1, catenin delta 1; PRC1, protein regulator of cytokinesis 1; CX32, connexin 32; FERMT2, FERM domain containing kindlin 2; OCT4, octamer-binding transcription factor 4; DDX39, DExD-box helicase 39A; PCL3, polycomb-like protein 3; ITGB5, integrin beta 5; JUB, LIM domain-containing protein ajuba; LRP16, LDL receptor related protein 16; ZIC5, zic family member 5; SOX9, SRY-box transcription factor 9; AKIP1, A-kinase interacting protein 1; FBXO17, F-box protein 17; FOXG1, forkhead box G1; GATA5, GATA binding protein 5; GRP78, endoplasmic reticulum chaperone BiP; HEG1, heart development protein with EGF like domains 1; NDRG3, NDRG (n-myc downstream-regulated gene) family member 3; MSI1, musashi RNA binding protein 1; p62/IMP2, insulin-like growth factor 2 mRNA binding protein 2; RICH2, ARHGAP44 Rho GTPase activating protein 44; AQP9, aquaporin 9; ARHGEF11, Rho guanine nucleotide exchange factor 11; GAL3, galectin-3; KIF2C, kinesin family member 2C; KIF18B, kinesin family member 18B; MTDH, metadherin; NRF1, NF-E2-related factor 1; FXR, farnesoid X receptor; USP1, ubiquitin specific protease 1; ATE1, arginyltransferase 1; PGC1 $\alpha$, peroxisome proliferator-activated receptor gamma coactivator 1-alpha; RAD54B, RAD54 (DNA repair and recombination protein) homolog B; ZEB1, zinc finger E-box binding homeobox 1.

\subsection{Wnt Signaling Pathway in Liver Cancer Stem Cell and Mesenchymal Stem Cell Biology}

Besides its roles in the above-mentioned processes that endow cancer cells with increased metastatic abilities, the Wnt signaling pathway is also active and contributes to the biology of other cells that are implicated in the metastatic outgrowth. For example, metastatic cancer spread is potentiated by cancer stem cells (CSC) which possess qualities that are characteristic of embryonic or adult stem cells. Those include self-renewal, differentiation, dormancy, and cellular plasticity which enables their adaptation to new environments. These abilities are needed for the successful establishment of metastasis [92]. The roles of Wnt signaling in CSCs biology is well described and has been a subject of several reviews $[93,94]$. In HCC, it was shown that deacetylation of $\beta$-catenin by SIRT1 
increases its protein stability and regulates self-renewal and oncogenesis of liver CSCs through promoting the transcription of Nanog [95]. Additionally, a small molecule inhibitor that inhibits Wnt / $\beta$-catenin signaling targets and depletes CD133+ / ALDH+ liver CSCs, which decreases their tumorigenicity in vitro and in vivo [96]. Sox9 is a member of the Sox proteins that are involved in human development by regulating lineage restriction, cell differentiation, and stem cell properties. It was shown that Sox 9 confers stemness properties in HCC and suppresses HCC cell migration, invasion, and in vivo lung metastasis through Frizzled-7 mediated Wnt/ $\beta$-catenin signaling [97]. In the mentioned publication, Frizzled7 was identified to be the direct transcriptional target of Sox9. A further paper confirmed the role of the above-mentioned signaling axis that includes Sox 9 and Wnt/ $\beta$-catenin in the self-renewal of liver CSCs [98]. Additionally, several miRNAs and lncRNAs have been shown to influence liver CSCs through the Wnt pathway [99]. These include miR-612 [100], miR-452 [101], miR-5188 [102], IncAPC [103], lncSAMMSON [104], and lncFZD6 [105].

Mesenchymal stem cells (MSCs) are multipotent adult stem cells that are present in multiple tissues. MSCs promote hepatocarcinogenesis and metastasis formation via signaling that includes activated Wnt/ $\beta$-catenin pathway and EMT [106]. Further to this, irradiated mesenchymal stem cells have been shown to increase the ratio of CD133+ HCC cells and support stemness maintenance of HCC stem cells through the Wnt/ $\beta$-catenin signaling pathway. This was reflected when liver CSCs were co-cultured with irradiated MSCs, which resulted in increased colony and tumor formation abilities via increased activity of the Wnt/ $\beta$-catenin signaling pathway [107]. In another study, it was also shown that overexpression of hepatocyte nuclear factor 4 alpha (HNF4a) in human MSCs inhibits HCC progression by reducing hepatoma cell growth, migration, and invasion through downregulation of the Wnt/ $\beta$-catenin signaling pathway [108].

\subsection{Wnt Signaling Pathway Affects the Communication between Different Components of the Liver Cancer Microenvironment That Promote Metastasis}

The activation of Wnt signaling in other components of a liver cancer microenvironment that promote metastasis has been documented. These include crosstalk between hepatic tumor cells and macrophages, which takes place via Wnt/ $\beta$-catenin signaling. This communication promotes M2-like macrophage polarization and tumor growth, migration, metastasis, and immunosuppression in HCC [109]. To confirm the role of Wnt signaling in this process, it was shown that lncRNA LINC00662 promotes M2 macrophage polarization and HCC progression via Wnt/ $\beta$-catenin signaling pathway [110]. Another component of a liver cancer microenvironment, hepatic stellate cells, have been shown to promote EMT, proliferation, invasiveness, and metastatic abilities of HCC in vitro and in vivo through microRNA-1246-ROR $\alpha$-Wnt/ $\beta$-catenin axis [111].

Angiogenesis is another important prerequisite for cancer cells to grow and metastasize. Wnt signaling is involved in vasculature formation [112] and in endothelial cell proliferation and migration [113]. Recently, angiocrine Tie-Wnt signaling axis in the liver controlling hepatocyte function during liver regeneration was described [114]. Moreover, angiocrine Wnt signaling controls liver growth and development of metabolic liver zonation in mice [115]. In HCC, miR-1301 was shown to inhibit angiogenesis, cell migration, and invasion in vitro and in vivo by decreasing $\mathrm{Wnt} / \beta$-catenin signaling through downregulation of BCL9, $\beta$-catenin, and VEGF expression in tumor cells. [116]. These papers add to the evidence that show that Wnt signaling affects many of the processes required for metastatic expansion, including vasculature formation.

\subsection{Wnt Signaling Pathway Is Activated in Residual HCC Cells after Incomplete Radiofrequency Ablation}

Some therapeutic approaches in HCC, like incomplete radiofrequency ablation (RFA), leave residual cancer cells behind. It was shown that incomplete RFA enhances invasiveness and metastasis of residual HCC cells by stimulating EMT-like phenotype changes through activation of the $\beta$-catenin signaling in HCCLM3 cells [117]. Another study has shown that insufficient radiofrequency ablation promotes the metastasis of residual hepato- 
cellular carcinoma cells via upregulating flotillin proteins which altered the EMT status and metastatic potential of heat-treated HCCLM3 cells by activating the Akt/Wnt/ $\beta$-catenin signaling pathway [118].

Taken together, the data presented in Section 3 confirm that the expression of the components of the Wnt pathway is de-regulated during HCC metastatic progression. Further, the Wnt pathway has been shown to strongly influence HCC EMT, motility, migration, invasion, and metastasis. It has a key role in CSCs, too, as well as in the biology of other components of the HCC microenvironment that potentiate the metastatic spread. Finally, after the treatment of HCC, the residual cancer cells, which are usually more aggressive and have higher metastatic abilities, show the activation of the Wnt pathway. Since the treatment options in advanced liver cancer are limited, the data presented here point to the possibility that targeting Wnt signaling pathways in liver cancers could alleviate metastasis related complications.

\section{Wnt Signaling Pathway Drives Secondary Liver Cancers}

Secondary liver cancers denote metastasis in the liver that originate from primary cancers from tissues other than the liver. Common primary cancers that metastasize to the liver include colorectal, lung, melanoma, breast, pancreatic, gastric, and prostate cancer.

\subsection{Colorectal Cancer Liver Metastasis}

Like mentioned above, colorectal cancer liver metastases represent a large cancerrelated burden and are, therefore, the most studied. In the colon, the Wnt signaling pathway is an essential mediator of tissue homeostasis and repair and is frequently de-regulated during cancer development. Almost all CRCs show hyperactivation of the WNT pathway, which is believed to be the initiating and driving event [119]. The most common mutation in CRC is inactivation of APC and in carriers of an APC inactivating mutations, the risk of CRC by the age of 40 is almost $100 \%$ [120]. For these reasons, the Wnt signaling pathway is an important target in anti-CRC treatment [121,122].

4.1.1. Aberrant Expression of Wnt Signaling Pathway Components Correlates with the Ability of CRC to Metastasize to the Liver

In the CRC metastasis to the liver, the expression of the Wnt signaling pathway components is highly de-regulated. Early on, it was noted that Wnt2 mRNA is frequently up regulated in colorectal polyps, primary CRC, and also in liver metastasis from CRC [123]. High Wnt6 expression in CRC tissue indicates unfavorable survival outcome for patients with CRC liver metastasis after liver resection suggesting that detection of Wnt6 expression may be valuable marker for guiding postoperative treatment [124]. On the other hand, nuclear $\beta$-catenin expression at the invasive front and in the vasculature predicts liver metastasis in CRC [125] and its overexpression in metastatic sentinel lymph node is strongly associated with synchronous liver metastasis and may contribute to predict liver metastasis [126]. Further, deregulated expression of nuclear $\beta$-catenin was associated with the development of liver metastasis, but not of CNS metastasis [127]. Co-expression of CD166/ $\beta$-catenin, CD44/ $\beta$-catenin, and CD44/CD166/ $\beta$-catenin were significant factors associated with liver metastasis, suggesting that specific combinations of CSC markers and $\beta$-catenin and additional analyzed proteins could be a significant predictor of poor survival in stage II CRC [128]. Finally, a recent study analyzing liver metastasis from different origins found that $\beta$-catenin overexpression was frequent in metastasis from CRC patients (27 out of 30 samples), but also breast (3/5), lungs $(1 / 2)$, and some other sites [129]. Another study analyzed the expression of $\beta$-catenin, APC, and Wnt1 in the primary tumor and corresponding metastasis of patients with CRC. In accordance with the above-mentioned results, the authors found a higher expression of nuclear $\beta$-catenin at the tumor invasion front, in the primary tumor, and the corresponding hepatic and lymphatic metastases. By contrast, APC expression was significantly lower in all analyzed tumor compartments compared with normal colonic mucosa. The same study found that Wnt1 protein expression was significantly lower in liver metastases but not in the primary tumor 
or lymphatic metastases compared with normal colonic mucosa [130]. An additional study adding to the hypothesis that the suppression of Wnt signaling pathway is a favorable event in CRC patients with metastasis, showed that high preoperative levels of circulating sFRP-5 predict better prognosis in those patients, and its levels are significantly lower in patients with either vascular invasion or liver metastasis [131].

\subsubsection{Mechanisms of Action of the Wnt Signaling Pathway in CRC Metastasis Process}

Mechanistically, Frizzled-7 expression has been suggested to promote survival, invasion, and metastatic characteristics of CRC cells through non-canonical and the canonical Wnt signaling pathways [132]. Among the downstream Wnt pathway events that lead to metastasis, new direct Wnt/ $\beta$-catenin target genes, BOP1, CKS2 and NFIL3, were identified and shown to induce EMT, cell migration, and experimental metastasis of CRC cells [133]. Further, it was shown that the SOX17/miR-371-5p/SOX2 axis suppresses EMT at least in part by inhibiting Wnt/ $\beta$-catenin signaling which leads to the inhibition of CRC metastasis [134]. Like with HCC metastasis, for CRC liver metastasis, numerous studies have shown that single protein or miRNA manipulation leads to the regulation of the Wnt pathway and in this way influences the CRC liver metastasis formation. These include cyclin dependent kinase 8 (CDK8) [135,136], HNF4a [137], sciellin (SCEL) [138], R-spondin 2 (RSPO2) [139], DNA methyltransferase 1 (DNMT) [140], the E2A gene (encodes two basic helix-loop-helix transcription factors, E12 and E47) [141], paired related homeobox 2 (PRRX2) [142], neuronal pentraxin 2 (NPTX2) [143], forkhead box P3 (FOXP3) [144], mitochondrial pyruvate carrier 1 (MPC1) [145], thyroid hormone receptor interactor 13 (TRIP13) [146], NUMB endocytic adaptor protein (NUMB) [147], ATM interactor (ATMIN) [148], FOS like 1, AP-1 transcription factor subunit (FOSL1) [149], arrestin

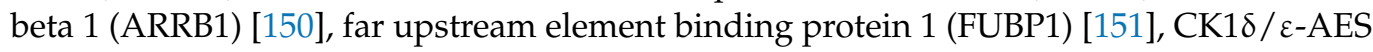
axis [152], etc.

Combined mutations of APC, KRAS, and TGFBR2 were shown to govern metastasis of intestinal cancer illustrating how key driver mutations in CRC cooperatively influence the development of a metastatic disease [153]. Adding to this data, it was shown by whole exome sequencing of CRC liver metastasis that the top three genes with the highest mutation frequency were TP53, APC, and KRAS [154]. This suggests that APC mutations are not only important during CRC development but are also playing an essential role in its metastasis formation.

Colon cancer metastases are often associated with activation of the Wnt/ $\beta$-catenin signaling pathway and high expression of the metastasis mediator S100A4. Studies have shown that inhibiting Wnt $\beta$-catenin signaling suppresses S100A4-dependent CRC liver metastasis, and, therefore, has a therapeutic potential $[155,156]$. Another protein frequently involved in positive regulation of CRC metastasis formation is the neural cell adhesion molecule L1 [157]. Gene coding for L1 is a target gene of $\beta$-catenin/TCF in CRC cells. L1 localizes preferentially to the invasive front of tumors and its forced expression confers increased cell motility, invasion, and tumorigenesis, and the induction of human CRC cell metastasis to the liver but does not require changes in EMT and CSCs markers [158]. This type of CRC cell metastasis formation is gaining attention recently and it is a subject of several studies that are trying to widen the knowledge on this process [157].

Regarding CRC CSCs, it was shown that those CSCs that express CD110, the thrombopoietin (TPO)-binding receptor, mediate liver metastasis. Further, TPO promotes metastasis of CD110+ CSCs to the liver by activating lysine degradation which generates acetylCoA that is subsequently used in p300-dependent LRP6 acetylation. This triggers tyrosine phosphorylation of LRP6, which activates Wnt signaling to promote self-renewal of CD110+ CSCs [159]. The importance of the Wnt pathway in CRC CSCs biology was also shown by the study that documented the significance of leucine-rich repeat-containing G-proteincoupled receptor 5 (Lgr5) in cancer stem cells in the colon and rectum [160]. Lgr5 is a Wnt target gene and is widely used as a marker of organ stem cells with self-renewal capacity [161]. 
4.1.3. Wnt Signaling Pathway Affects the Communication between Different Components of the CRC Microenvironment That Promote Metastasis

Metastasis formation is a process involving a multitude of different cells that act in concert in the primary tumor microenvironment, but also at the secondary site. In a microenvironment of a CRC primary tumor, it was shown that cancer-associated fibroblasts (CAFs) play an important role in metastasis formation. For example, CAF secreted exosomes promote metastasis and chemotherapy resistance by enhancing cell stemness and EMT. Mechanistically, CAFs promote the transferring of exosomes to CRC cells, leading to an increase of miR-92a-3p level in CRC cells, which activates the Wnt/ $\beta$-catenin pathway and inhibits mitochondrial apoptosis contributing to cell stemness, EMT, metastasis, and 5-FU/L-OHP resistance [162]. In a study where conditioned medium (CM) from normal colonic fibroblasts, CAFs from primary tumor (CAF-PT) or liver metastasis (CAF-LM) were used the influence of each CM on CRC cell lines was tested. In this way, it was shown that the liver microenvironment induces more efficiently the aggressiveness of CRC cells but secondarily evokes cell death. The transcriptomic profile of CRC cells treated with CAFLM CM was associated with Wnt and MAPK pathways activation in gene set enrichment analysis [163]. Another study showed that intervention with BCL9 activity and expression modulates the cellular landscape of CAFs in the tumor-immune microenvironment of CRC. Moreover, CAFs affect cancer-associated immune surveillance by inhibition of the Wnt signaling pathway [164]. CAF-derived Wnt2 increases tumor angiogenesis in colon cancer both in vitro and in vivo [165]. In regard to angiogenesis, it was shown that lncRNA GAS5 inhibits angiogenesis, invasion, and metastasis of CRC through the Wnt/ $\beta$-catenin signaling pathway [166]. Additionally, Wnt/ $\beta$-catenin signaling was shown to influence many of the processes involved in vasculature formation in CRC, like sprouting and nonsprouting angiogenesis, vasculogenic mimicry, and the formation of mosaic vessels [167].

In the light of involvement of other cells in the metastasis process, single-cell transcriptome analysis revealed granulocytes enrichment and tumor-immune microenvironment heterogenicity in CRC liver metastases. In this context, the Wnt signaling pathway was found to be activated and promote granulocytes migration [168].

\subsection{Breast Cancer Liver Metastasis}

Like mentioned above, several cancers other than CRC frequently metastasize to the liver. Studies have shown the importance of the Wnt signaling in those processes. For example, it was shown that AF1q is a novel TCF7 co-factor that specifically binds to TCF7 in the Wnt signaling pathway and results in transcriptional activation of CD44 as well as transcription of multiple downstream targets of the TCF7/LEF1. In this way, AF1q promotes breast cancer metastasis including those to the liver [169]. Ablation of Frizzled-6 expression in mammary cancer cell lines inhibited motility and invasion, induced a more symmetrical shape of organoid three-dimensional cultures, and inhibited bone and liver metastasis. Further to this, multivariate analysis suggested an independent prognostic significance of Frizzled-6 expression in triple-negative breast cancer (TNBC), predicting distant relapse [170]. Another study has shown that $\beta$-catenin-independent Wnt signaling and Ki67 are associated with poor prognosis in patients with breast cancer liver metastases [171]. Moreover, simultaneous metastases in liver, ovaries, and bone from chemo-resistant TNBC are prevented by interfering with the Wnt signaling pathway, suggesting that inhibition of the Wnt pathway treats multi-organ metastases of TNBC [172].

\subsection{Gastric Cancer Liver Metastasis}

In gastric cancer, it was shown that $\beta$-catenin expression is lost in a subgroup of primary gastric cancers. It is also frequently absent in metastases, and exhibits nuclear localization in cancers with either $\beta$-catenin or APC gene mutations [173]. In contrast with this, the paper showed that Twist promotes gastric cancer cell migration, invasion, and metastasis. The same paper suggests that Twist may play an important role in Wnt/TCF4 signaling because overexpression of Twist in MKN28 cells increased TCF4/LEF DNA 
binding activity, and promoted expression of TCF4's downstream target genes, CCND1 and MMP-2 [174]. Supporting the positive role of Wnt signaling in gastric cell metastasis, a study has shown that blocking Wnt5a by antibody suppresses in vitro migration and invasion and in vivo metastasis formation of gastric cancer cells by inhibiting its receptormediated endocytosis [175]. In addition, RYK, a receptor of noncanonical Wnt ligand Wnt5a, is positively correlated with gastric cancer tumorigenesis and, specifically, the potential of liver metastasis [176]. Further to this, Dvl-associating protein with a high frequency of leucine residues (Daple) was shown to mediate Wnt5a-induced Rac and JNK activation, laminin c2 expression, and cell migration and invasion. According to these in vitro-obtained results, Daple depletion suppressed liver metastasis in a mouse xenograft model of gastric cancer, suggesting that the non-canonical Wnt signaling pathway contributes to gastric cancer progression at least partly via Daple [177].

\subsection{Lung Cancer Liver Metastasis}

In lung cancer, it was shown that Glypican-5 suppresses EMT of the lung adenocarcinoma by competitively binding to Wnt3a and inactivating the Wnt/ $\beta$-catenin signaling pathway [178]. Besides Wnt3a, Wnt5a was also found to enhance EMT, invasion, migration, and metastasis in vitro and in vivo in non-small-cell lung cancer [179]. Further, Destrin (DSTN), a member of ADF/cofilin family of proteins, was shown to contribute to lung adenocarcinoma progression, including liver metastasis. Mechanistically, DSTN facilitates nuclear translocation of $\beta$-catenin, which promotes EMT [180].

\subsection{Melanoma Liver Metastasis}

The studies on the role of Wnt signaling in melanoma progression are scarce. However, recent study has shown that Wnt signaling enhances neural crest migration of melanoma cells and induces an invasive phenotype, emphasizing the essential role of embryonic EMT-inducing neural crest signaling for the spreading of malignant melanoma [181].

\subsection{Pancreatic Cancer Liver Metastasis}

As shown in Figure 1, pancreatic cancer often progresses to form liver metastasis. An early study has shown that aberrant expression of $\beta$-catenin and E-cadherin correlated strongly with lymph node spread and liver metastases in pancreatic endocrine tumors [182]. In further studies, it has been shown that BCL9L plays an important role in TGF- $\beta$-induced EMT and metastasis of pancreatic cancer through its effects on E-cadherin and $\beta$-catenin [183]. Several other studies investigated the roles of molecules that converge to Wnt signaling pathway and influence pancreatic cell metastasis. These include semaphorin 5a (SEMA5A) [184], lncRNA DLX6-AS1 [185], activator of transcription and developmental regulator (AUTS2) [186], cadherin 13 (CDH13) [187], and lncRNA 00261 [188].

\subsection{Prostate Cancer Liver Metastasis}

Prostate cancer is another cancer type with frequent liver metastasis. The results from my recent work [189], which is a meta-analysis of the gene expression data, show that many of the genes whose expression changes specifically in liver metastasis in comparison to primary prostate cancer belong to the enriched term of the Wnt signaling. Those include genes coding for sFRP-1, Frizzled related protein (FRZB), Frizzled-6, Frizzled-7, ROR1, LRP1, LRP6, GSK3B, TCF7, BCL9, CCND2, CAMK2G, Dishevelled associated activator of morphogenesis 2 (DAAM2), and Ras homolog family member A (RHOA). Although some of the antagonists of Wnt pathway are significantly down-regulated, also, some of the positive regulators of the pathway are slightly down-regulated, so it would be hard to conclude on the status of the Wnt signaling pathway in these samples. However, considering the number of the components with changed expression, Wnt pathway deregulation in prostate cancer liver metastasis is recognized and could serve as an initial point for further studies. For example, a study has shown that DKK1 expression increases early in prostate cancer development and decreases during progression from primary tumor 
to metastasis, which would indicate the activation of the Wnt pathway [190]. Additionally, a recent study presented a new model of multi-visceral and bone metastatic prostate cancer with activation of Notch and Wnt pathways [191] adding to the complexity of Wnt signaling in contribution to a metastatic process in prostate cancer.

In conclusion, the data presented in Section 4 point to the de-regulated Wnt signaling pathway in liver metastasis from different primary tumors. They also confirm involvement of the Wnt pathway in the many of the steps that are required for the metastatic outgrowth and that are schematically outlined in Figure 1.

\section{Conclusions}

Liver metastasis, originating either from primary liver or other cancer types, represents a large cancer-related complication. Wnt signaling pathway is considered in the treatment of HCC and primary cancers, like CRC, that often metastasize to the liver [15,16,121,122]. Herein, the data that show critical involvement of Wnt pathway in many of the steps that are required for liver metastasis in different scenarios are presented. Therefore, the information outlined in these chapters contributes to the idea that Wnt pathway is among the drivers of liver metastasis and that its targeting could potentially relieve the liver metastasis-related burdens. To that end, selective inhibitors of Wnt pathway could be used alone or in combination to treat patients with advanced liver metastasis. Future studies that will describe their efficacy and toxicity are needed. This is especially important, because the vast majority of cancer-related deaths are caused by metastasis formation and the current anti-cancer therapies mainly target primary cancers. Therefore, therapies that effectively target metastasis should significantly contribute to the success of anti-cancer treatments.

Funding: This research was funded by My Zaba Start 2019 donation from Zagrebačka banka.

Institutional Review Board Statement: Not applicable.

Informed Consent Statement: Not applicable.

Conflicts of Interest: The author declares no conflict of interest.

\section{References}

1. Llovet, J.M.; Zucman-Rossi, J.; Pikarsky, E.; Sangro, B.; Schwartz, M.; Sherman, M.; Gores, G. Hepatocellular carcinoma. Nat. Rev. Dis. Primers 2016, 14, 16018. [CrossRef]

2. Llovet, J.M.; Kelley, R.K.; Villanueva, A.; Singal, A.G.; Pikarsky, E.; Roayaie, S.; Lencioni, R.; Koike, K.; Zucman-Rossi, J.; Finn, R.S. Hepatocellular carcinoma. Nat. Rev. Dis. Primers 2021, 7, 6. [CrossRef]

3. Tsilimigras, D.I.; Brodt, P.; Clavien, P.A.; Muschel, R.J.; D’Angelica, M.I.; Endo, I.; Parks, R.W.; Doyle, M.; de Santibañes, E.; Pawlik, T.M. Liver metastases. Nat. Rev. Dis. Primers 2021, 7, 27. [CrossRef] [PubMed]

4. Sung, H.; Ferlay, J.; Siegel, R.L.; Laversanne, M.; Soerjomataram, I.; Jemal, A.; Bray, F. Global cancer statistics 2020: GLOBOCAN estimates of incidence and mortality worldwide for 36 cancers in 185 countries. Cancer J. Clin. 2021, 71, 209-249. [CrossRef] [PubMed]

5. Clevers, H. Wnt/ $\beta$-catenin signaling in development and disease. Cell 2006, 127, 469-480. [CrossRef] [PubMed]

6. Yang, Y.; Mlodzik, M. Wnt-frizzled/planar cell polarity signaling: Cellular orientation by facing the wind (Wnt). Annu. Rev. Cell Dev. Biol. 2015, 13, 623-646. [CrossRef]

7. De, A. Wnt/Ca 2 signaling pathway: A brief overview. Acta Biochim. Biophys. Sin. 2011, 43, 745-756. [CrossRef]

8. Kestler, H.A.; Kühl, M. From individual Wnt pathways towards a Wnt signalling network. Philos. Trans. R. Soc. B Biol. Sci. 2008, 363, 1333-1347. [CrossRef]

9. Das, S.; Yu, S.; Sakamori, R.; Stypulkowski, E.; Gao, N. Wntless in Wnt secretion: Molecular, cellular and genetic aspects. Front. Biol. 2012, 7, 587-593. [CrossRef]

10. Malinauskas, T.; Jones, E.Y. Extracellular modulators of Wnt signalling. Curr. Opin. Struct. Biol. 2014, 29, 77-84. [CrossRef]

11. He, S.; Tang, S. WNT / $\beta$-catenin signaling in the development of liver cancers. Biomed. Pharmacother. 2020, 132, 110851. [CrossRef]

12. Khalaf, A.M.; Fuentes, D.; Morshid, A.I.; Burke, M.R.; Kaseb, A.O.; Hassan, M.; Hazle, J.D.; Elsayes, K.M. Role of Wnt/ $\beta$-catenin signaling in hepatocellular carcinoma, pathogenesis, and clinical significance. J. Hepatocell. Carcinoma 2018, 27, 61-73. [CrossRef]

13. Kwee, S.A.; Tiirikainen, M. Beta-catenin activation and immunotherapy resistance in hepatocellular carcinoma: Mechanisms and biomarkers. Hepatoma Res. 2021, 7, 8. [CrossRef] [PubMed]

14. Martin-Orozco, E.; Sanchez-Fernandez, A.; Ortiz-Parra, I.; Ayala-San Nicolas, M. WNT signaling in tumors: The way to evade drugs and immunity. Front. Immunol. 2019, 10, 2854. [CrossRef] [PubMed] 
15. Vilchez, V.; Turcios, L.; Marti, F.; Gedaly, R. Targeting Wnt/ $\beta$-catenin pathway in hepatocellular carcinoma treatment. World J. Gastroenterol. 2016, 22, 823-832. [CrossRef]

16. Chen, J.; Rajasekaran, M.; Hui, K.M. Atypical regulators of Wnt/ $\beta$-catenin signaling as potential therapeutic targets in Hepatocellular Carcinoma. Exp. Biol. Med. 2017, 242, 1142-1149. [CrossRef]

17. Chen, J.; Liu, J.; Jin, R.; Shen, J.; Liang, Y.; Ma, R.; Lin, H.; Liang, X.; Yu, H.; Cai, X. Cytoplasmic and/or nuclear expression of $\beta$-catenin correlate with poor prognosis and unfavorable clinicopathological factors in hepatocellular carcinoma: A meta-analysis. PLoS ONE 2014, 9, e111885. [CrossRef] [PubMed]

18. Pan, L.H.; Yao, M.; Cai, Y.; Gu, J.J.; Yang, X.L.; Wang, L.; Yao, D.F. Oncogenic Wnt3a expression as an estimable prognostic marker for hepatocellular carcinoma. World J. Gastroenterol. 2016, 22, 3829-3836. [CrossRef] [PubMed]

19. Zhang, C.; Li, C.; Chen, X.; Zhou, Y.; Yin, B.; Ni, R.; Zhang, Y.; Liu, J. Overexpression of dishevelled 2 is involved in tumor metastasis and is associated with poor prognosis in hepatocellular carcinoma. Clin. Transl. Oncol. 2017, 19, 1507-1517. [CrossRef] [PubMed]

20. Jiang, Y.; Zhou, X.D.; Liu, Y.K.; Wu, X.; Huang, X.W. Association of hTcf-4 gene expression and mutation with clinicopathological characteristics of hepatocellular carcinoma. World J. Gastroenterol. 2002, 8, 804-807. [CrossRef]

21. Hyeon, J.; Ahn, S.; Lee, J.J.; Song, D.H.; Park, C.K. Prognostic significance of bcl9 expression in hepatocellular carcinoma. Korean J. Pathol. 2013, 47, 130-136. [CrossRef]

22. Shi, Y.; Bai, J.; Guo, S.; Wang, J. Wntless is highly expressed in advanced-stage intrahepatic cholangiocarcinoma. Tohoku J. Exp. Med. 2018, 244, 195-199. [CrossRef] [PubMed]

23. Zucchini-Pascal, N.; Peyre, L.; Rahmani, R. Crosstalk between beta-catenin and snail in the induction of epithelial to mesenchymal transition in hepatocarcinoma: Role of the ERK1/2 pathway. Int. J. Mol. Sci. 2013, 14, 20768-20792. [CrossRef] [PubMed]

24. Zhang, Q.; Bai, X.; Chen, W.; Ma, T.; Hu, Q.; Liang, C.; Xie, S.; Chen, C.; Hu, L.; Xu, S.; et al. Wnt/ $\beta$-catenin signaling enhances hypoxia-induced epithelial-mesenchymal transition in hepatocellular carcinoma via crosstalk with hif- $1 \alpha$ signaling. Carcinogenesis 2013, 34, 962-973. [CrossRef]

25. Xu, W.; Zhou, W.; Cheng, M.; Wang, J.; Liu, Z.; He, S.; Luo, X.; Huang, W.; Chen, T.; Yan, W.; et al. Hypoxia activates Wnt/ $\beta-$ catenin signaling by regulating the expression of BCL9 in human hepatocellular carcinoma. Sci. Rep. 2017, 7, 40446. [CrossRef] [PubMed]

26. Steinway, S.N.; Zanudo, J.G.T.; Ding, W.; Rountree, C.B.; Feith, D.J.; Loughran, T.P.; Albert, R. Network modeling of TGF $\beta$ signaling in hepatocellular carcinoma epithelial-to-mesenchymal transition reveals joint sonic hedgehog and Wnt pathway activation. Cancer Res. 2014, 74, 5963-5977. [CrossRef] [PubMed]

27. Asano, T.; Yamada, S.; Fuchs, B.C.; Takami, H.; Hayashi, M.; Sugimoto, H.; Fujii, T.; Tanabe, K.K.; Kodera, Y. Clinical implication of Frizzled 2 expression and its association with epithelial-to-mesenchymal transition in hepatocellular carcinoma. Int. J. Oncol. 2017, 50, 1647-1654. [CrossRef] [PubMed]

28. Gujral, T.S.; Chan, M.; Peshkin, L.; Sorger, P.K.; Kirschner, M.W.; Macbeath, G. A noncanonical frizzled2 pathway regulates epithelial-mesenchymal transition and metastasis. Cell 2014, 159, 844-856. [CrossRef] [PubMed]

29. Lu, C.; He, Y.; Duan, J.; Yang, Y.; Zhong, C.; Zhang, J.; Liao, W.; Huang, X.; Zhu, R.; Li, M. Expression of Wnt3a in hepatocellular carcinoma and its effects on cell cycle and metastasis. Int. J. Oncol. 2017, 159, 844-856. [CrossRef]

30. Huang, W.J.; Tian, X.P.; Bi, S.X.; Zhang, S.R.; He, T.S.; Song, L.Y.; Yun, J.P.; Zhou, Z.G.; Yu, R.M.; Li, M. The $\beta$-catenin/TCF-4LINC01278-miR-1258-Smad2/3 axis promotes hepatocellular carcinoma metastasis. Oncogene 2020, 39, 4538-4550. [CrossRef]

31. Cetin, G.O.; Toylu, A.; Atabey, N.; Sercan, Z.; Sakizli, M. Downregulation of VANGL1 inhibits cellular invasion rather than cell motility in hepatocellular carcinoma cells without stimulation. Genet. Test. Mol. Biomarkers 2015, 19, 283-287. [CrossRef]

32. Jiang, G.X.; Liu, W.; Cui, Y.F.; Zhong, X.Y.; Tai, S.; Wang, Z.D.; Shi, Y.G.; Li, C.L.; Zhao, S.Y. Reconstitution of secreted frizzledrelated protein 1 suppresses tumor growth and lung metastasis in an orthotopic model of hepatocellular carcinoma. Dig. Dis. Sci. 2010, 55, 2838-2843. [CrossRef]

33. Song, G.; Cao, H.X.; Yao, S.X.; Li, C.T. Abnormal expression of WIF1 in hepatocellular carcinoma cells and its regulating effect on invasion and metastasis factors of TIMP-3 and caveolin-1 of hepatocellular carcinoma. Asian Pac. J. Trop. Med. 2015, 8, 958-963. [CrossRef]

34. Chen, L.; Li, M.; Li, Q.; Wang, C.J.; Xie, S.Q. DKK1 promotes hepatocellular carcinoma cell migration and invasion through $\beta$-catenin/MMP7 signaling pathway. Mol. Cancer 2013, 12, 157. [CrossRef] [PubMed]

35. Fezza, M.; Moussa, M.; Aoun, R.; Haber, R.; Hilal, G. DKK1 promotes hepatocellular carcinoma inflammation, migration and invasion: Implication of TGF- $\beta 1$. PLoS ONE 2019, 14, e0223252. [CrossRef]

36. Tao, Y.M.; Liu, Z.; Liu, H.L. Dickkopf-1 (DKK1) promotes invasion and metastasis of hepatocellular carcinoma. Dig. Liver Dis. 2013, 45, 251-257. [CrossRef] [PubMed]

37. Liao, C.H.; Yeh, C.T.; Huang, Y.H.; Wu, S.M.; Chi, H.C.; Tsai, M.M.; Tsai, C.Y.; Liao, C.J.; Tseng, Y.H.; Lin, Y.H.; et al. Dickkopf 4 positively regulated by the thyroid hormone receptor suppresses cell invasion in human hepatoma cells. Hepatology 2012, 55, 910-920. [CrossRef]

38. Li, J.; Gong, W.; Li, X.; Wan, R.; Mo, F.; Zhang, Z.; Huang, P.; Hu, Z.; Lai, Z.; Lu, X.; et al. Recent Progress of Wnt Pathway Inhibitor Dickkopf-1 in Liver Cancer. J. Nanosci. Nanotechnol. 2018, 18, 5192-5206. [CrossRef]

39. Wang, C.; Wang, X.; Su, Z.; Fei, H.; Liu, X.; Pan, Q. miR-25 promotes hepatocellular carcinoma cell growth, migration and invasion by inhibiting RhoGDI1. Oncotarget 2015, 6, 36231-36244. [CrossRef] [PubMed] 
40. Zhang, Z.; Yin, J.; Yang, J.; Shen, W.; Zhang, C.; Mou, W.; Luo, J.; Yan, H.; Sun, P.; Luo, Y.; et al. miR-885-5p suppresses hepatocellular carcinoma metastasis and inhibits Wnt/ $\beta$-catenin signaling pathway. Oncotarget 2016, 7, 75038-75051. [CrossRef] [PubMed]

41. Zhang, J.G.; Shi, Y.; Hong, D.F.; Song, M.; Huang, D.; Wang, C.Y.; Zhao, G. MiR-148b suppresses cell proliferation and invasion in hepatocellular carcinoma by targeting WNT1/ $\beta$-catenin pathway. Sci. Rep. 2015, 5, 8087. [CrossRef]

42. Tang, J.; Li, L.; Huang, W.; Sui, C.; Yang, Y.; Lin, X.; Hou, G.; Chen, X.; Fu, J.; Yuan, S.; et al. MiR-429 increases the metastatic capability of HCC via regulating classic Wnt pathway rather than epithelial-mesenchymal transition. Cancer Lett. 2015, 364, 33-43. [CrossRef]

43. Hu, Z.; Wang, P.; Lin, J.; Zheng, X.; Yang, F.; Zhang, G.; Chen, D.; Xie, J.; Gao, Z.; Peng, L.; et al. MicroRNA-197 promotes metastasis of hepatocellular carcinoma by activating wnt/ $\beta$-catenin signaling. Cell. Physiol. Biochem. 2018, 51, 470-486. [CrossRef] [PubMed]

44. Jia, P.; Wei, G.; Zhou, C.; Gao, Q.; Wu, Y.; Sun, X.; Li, X. Upregulation of MiR-212 inhibits migration and tumorigenicity and inactivates Wnt/ $\beta$-catenin signaling in human hepatocellular carcinoma. Technol. Cancer Res. Treat. 2018, 17, 533034618765221. [CrossRef] [PubMed]

45. Yao, B.; Li, Y.; Wang, L.; Chen, T.; Niu, Y.; Liu, Q.; Liu, Z. MicroRNA-3194-3p inhibits metastasis and epithelial-mesenchymal transition of hepatocellular carcinoma by decreasing Wnt/ $\beta$-catenin signaling through targeting BCL9. Artif. Cells Nanomed. Biotechnol. 2019, 47, 3885-3895. [CrossRef] [PubMed]

46. Wang, H.; Ou, J.; Jian, Z.; Ou, Y. miR-186 modulates hepatocellular carcinoma cell proliferation and mobility via targeting MCRS1-mediated Wnt/ $\beta$-catenin signaling. J. Cell. Physiol. 2019, 234, 23135-23145. [CrossRef]

47. Huang, F.I.; Chen, Y.L.; Chang, C.N.; Yuan, R.H.; Jeng, Y.M. Hepatocyte growth factor activates Wnt pathway by transcriptional activation of LEF1 to facilitate tumor invasion. Carcinogenesis 2012, 33, 1142-1148. [CrossRef] [PubMed]

48. Chen, Y.L.; Wang, T.H.; Hsu, H.C.; Yuan, R.H.; Jeng, Y.M. Overexpression of CTHRC1 in hepatocellular carcinoma promotes tumor invasion and predicts poor prognosis. PLoS ONE 2013, 8, e70324. [CrossRef] [PubMed]

49. Yu, H.; Shen, H.; Zhang, Y.; Zhong, F.; Liu, Y.; Qin, L.; Yang, P. CAV1 promotes HCC cell progression and metastasis through Wnt/ $\beta$-catenin pathway. PLoS ONE 2014, 9, e106451. [CrossRef]

50. Jiang, L.; Yang, Y.D.; Fu, L.; Xu, W.; Liu, D.; Liang, Q.; Zhang, X.; Xu, L.; Guan, X.Y.; Wu, B.; et al. CLDN3 inhibits cancer aggressiveness via Wnt-EMT signaling and is a potential prognostic biomarker for hepatocellular carcinoma. Oncotarget 2014, 5, 7663-7676. [CrossRef]

51. Srivastava, J.; Siddiq, A.; Gredler, R.; Shen, X.N.; Rajasekaran, D.; Robertson, C.L.; Subler, M.A.; Windle, J.J.; Dumur, C.I.; Mukhopadhyay, N.D.; et al. Astrocyte elevated gene-1 and c-Myc cooperate to promote hepatocarcinogenesis in mice. Hepatology 2015, 61, 915-929. [CrossRef]

52. Bacigalupo, M.L.; Manzi, M.; Espelt, M.V.; Gentilini, L.D.; Compagno, D.; Laderach, D.J.; Wolfenstein-Todel, C.; Rabinovich, G.A.; Troncoso, M.F. Galectin-1 Triggers epithelial-mesenchymal transition in human hepatocellular carcinoma cells. J. Cell. Physiol. 2015, 230, 1298-1309. [CrossRef] [PubMed]

53. Jiang, J.; Yu, C.; Chen, M.; Tian, S.; Sun, C. Over-expression of TRIM37 promotes cell migration and metastasis in hepatocellular carcinoma by activating Wnt/ $\beta$-catenin signaling. Biochem. Biophys. Res. Commun. 2015, 464, 1120-1127. [CrossRef] [PubMed]

54. Zhang, Z.; Huang, S.; Wang, H.; Wu, J.; Chen, D.; Peng, B.; Zhou, Q. High expression of hexokinase domain containing 1 is associated with poor prognosis and aggressive phenotype in hepatocarcinoma. Biochem. Biophys. Res. Commun. 2016, 474, 673-679. [CrossRef] [PubMed]

55. Fan, W.H.; Du, F.J.; Liu, X.J.; Chen, N. Knockdown of FRAT1 inhibits hypoxia-induced epithelialto-mesenchymal transition via suppression of the Wnt/ $\beta$-catenin pathway in hepatocellular carcinoma cells. Oncol. Rep. 2016, 36, 2999-3004. [CrossRef]

56. Ye, Y.; Long, X.; Zhang, L.; Chen, J.; Liu, P.; Li, H.; Wei, F.; Yu, W.; Ren, X.; Yu, J. NTS/NTR1 co-expression enhances epithelial-tomesenchymal transition and promotes tumor metastasis by activating the Wnt/ $\beta$-catenin signaling pathway in hepatocellular carcinoma. Oncotarget 2016, 7, 70303-70322. [CrossRef]

57. Tang, B.; Tang, F.; Wang, Z.; Qi, G.; Liang, X.; Li, B.; Yuan, S.; Liu, J.; Yu, S.; He, S. Overexpression of CTNND1 in hepatocellular carcinoma promotes carcinous characters through activation of Wnt/ $\beta$-catenin signaling. J. Exp. Clin. Cancer Res. 2016, 35, 82. [CrossRef]

58. Chen, J.; Rajasekaran, M.; Xia, H.; Zhang, X.; Kong, S.N.; Sekar, K.; Seshachalam, V.P.; Deivasigamani, A.; Goh, B.K.P.; Ooi, L.L.; et al. The microtubule-associated protein PRC1 promotes early recurrence of hepatocellular carcinoma in association with the Wnt/ $\beta$-catenin signalling pathway. Gut 2016, 65, 1522-1534. [CrossRef]

59. Yan, Y.; Na, Z.; Zhu, J.; Hong, X.T.; Liu, H.; Ou, Y.R.; Su, F.; Rui, W.; Li, Y.M.; Wu, Q. Downregulated connexin32 promotes EMT through the Wnt/ $\beta$-catenin pathway by targeting Snail expression in hepatocellular carcinoma. Int. J. Oncol. 2017, 50, 1977-1988. [CrossRef]

60. Lin, J.; Lin, W.; Ye, Y.; Wang, L.; Chen, X.; Zang, S.; Huang, A. Kindlin-2 promotes hepatocellular carcinoma invasion and metastasis by increasing Wnt/ $\beta$-catenin signaling. J. Exp. Clin. Cancer Res. 2017, 36, 134. [CrossRef]

61. Sun, L.; Liu, T.; Zhang, S.; Guo, K.; Liu, Y. Oct4 induces EMT through LEF1/ $\beta$-catenin dependent WNT signaling pathway in hepatocellular carcinoma. Oncol. Lett. 2017, 13, 2599-2606. [CrossRef]

62. Zhang, T.; Ma, Z.; Liu, L.; Sun, J.; Tang, H.; Zhang, B.; Zou, Y.; Li, H. DDX39 promotes hepatocellular carcinoma growth and metastasis through activating Wnt/ $\beta$-catenin pathway article. Cell Death Dis. 2018, 9, 675. [CrossRef] 
63. Cai, Z.; Qian, Z.Y.; Jiang, H.; Ma, N.; Li, Z.; Liu, L.Y.; Ren, X.X.; Shang, Y.R.; Wang, J.J.; Li, J.J.; et al. hPCL3s promotes hepatocellular carcinoma metastasis by activating b-catenin signaling. Cancer Res. 2018, 78, 2536-2549. [CrossRef]

64. Lin, Z.; He, R.; Luo, H.; Lu, C.; Ning, Z.; Wu, Y.; Han, C.; Tan, G.; Wang, Z. Integrin- $\beta 5$, a MIR-185-targeted gene, promotes hepatocellular carcinoma tumorigenesis by regulating $\beta$-catenin stability. J. Exp. Clin. Cancer Res. 2018, 37, 17. [CrossRef]

65. Wang, H.; Wang, J.; Shi, X.; Ding, Y. JUB induces epithelial-mesenchymal transition via the Wnt/ $\beta$-catenin signaling pathway in hepatocellular carcinoma cells. Int. J. Clin. Exp. Pathol. 2018, 11, 1374-1382.

66. Shao, L.; Jing, W.; Wang, L.; Pan, F.; Wu, L.; Zhang, L.; Yang, P.; Hu, M.; Fan, K. LRP16 prevents hepatocellular carcinoma progression through regulation of Wnt/ $\beta$-catenin signaling. J. Mol. Med. 2018, 96, 547-558. [CrossRef] [PubMed]

67. Liu, L.; Hu, X.; Sun, D.; Wu, Y.; Zhao, Z. ZIC5 facilitates the growth of hepatocellular carcinoma through activating Wnt/ $\beta$-catenin pathway. Biochem. Biophys. Res. Commun. 2018, 503, 2173-2179. [CrossRef] [PubMed]

68. Zhang, W.; Wu, Y.; Hou, B.; Wang, Y.; Deng, D.; Fu, Z.; Xu, Z. A SOX9-AS1/miR-5590-3p/SOX9 positive feedback loop drives tumor growth and metastasis in hepatocellular carcinoma through the Wnt/ $\beta$-catenin pathway. Mol. Oncol. 2019, 13, 2194-2210. [CrossRef]

69. Cui, Y.; Wu, X.; Lin, C.; Zhang, X.; Ye, L.; Ren, L.; Chen, M.; Yang, M.; Li, Y.; Li, M.; et al. AKIP1 promotes early recurrence of hepatocellular carcinoma through activating the Wnt/ $\beta$-catenin/CBP signaling pathway. Oncogene 2019, 38, 5516-5529. [CrossRef] [PubMed]

70. Liu, F.H.; Cui, Y.P.; He, Y.K.; Shu, R.H. FBXO17 promotes malignant progression of hepatocellular carcinoma by activating wnt/ $\beta$-catenin pathway. Eur. Rev. Med. Pharmacol. Sci. 2019, 23, 8265-8273. [CrossRef] [PubMed]

71. Zheng, X.; Lin, J.; Wu, H.; Mo, Z.; Lian, Y.; Wang, P.; Hu, Z.; Gao, Z.; Peng, L.; Xie, C. Forkhead box (FOX) G1 promotes hepatocellular carcinoma epithelial-mesenchymal transition by activating Wnt signal through forming T-cell factor-4/Betacatenin/FOXG1 complex. J. Exp. Clin. Cancer Res. 2019, 38, 475. [CrossRef]

72. Feng, H.; Zhu, M.; Zhang, R.; Wang, Q.; Li, W.; Dong, X.; Chen, Y.; Lu, Y.; Liu, K.; Lin, B.; et al. GATA5 inhibits hepatocellular carcinoma cells malignant behaviours by blocking expression of reprogramming genes. J. Cell. Mol. Med. 2019, 23, $2536-2548$. [CrossRef] [PubMed]

73. Xiong, H.; Xiao, H.; Luo, C.; Chen, L.; Liu, X.; Hu, Z.; Zou, S.; Guan, J.; Yang, D.; Wang, K. GRP78 activates the Wnt/HOXB9 pathway to promote invasion and metastasis of hepatocellular carcinoma by chaperoning LRP6. Exp. Cell Res. 2019, $383,111493$. [CrossRef] [PubMed]

74. Zhao, Y.R.; Wang, J.L.; Xu, C.; Li, Y.M.; Sun, B.; Yang, L.Y. HEG1 indicates poor prognosis and promotes hepatocellular carcinoma invasion, metastasis, and EMT by activating Wnt/ $\beta$-catenin signaling. Clin. Sci. 2019, 133, 1645-1662. [CrossRef] [PubMed]

75. Shi, J.K.; Zheng, H.Z.; Yuan, L.Y. High NDRG3 expression facilitates HCC metastasis by promoting nuclear translocation of $\beta$-catenin. BMB Rep. 2019, 52, 451-456. [CrossRef] [PubMed]

76. Liu, Q.; Zhou, C.; Zhang, B. Upregulation of musashi1 increases malignancy of hepatocellular carcinoma via the Wnt/ $\beta$-catenin signaling pathway and predicts a poor prognosis. BMC Gastroenterol. 2019, 19, 230. [CrossRef] [PubMed]

77. Xing, M.; Li, P.; Wang, X.; Li, J.; Shi, J.; Qin, J.; Zhang, X.; Ma, Y.; Francia, G.; Zhang, J.Y. Overexpression of p62/IMP2 can promote cell migration in hepatocellular carcinoma via activation of the wnt/ $\beta$-catenin pathway. Cancers 2020, 12, 7. [CrossRef]

78. Zhang, J.; Yang, C.; Gong, L.; Zhu, S.; Tian, J.; Zhang, F.; Zhu, Q.; Wang, J.; Lan, M.; Li, Y.; et al. RICH2, a potential tumor suppressor in hepatocellular carcinoma. Front. Biosci.-Landmark 2019, 24, 1363-1376. [CrossRef]

79. Liao, S.; Chen, H.; Liu, M.; Gan, L.; Li, C.; Zhang, W.; Lv, L.; Mei, Z. Aquaporin 9 inhibits growth and metastasis of hepatocellular carcinoma cells via Wnt/ $\beta$-catenin pathway. Aging 2020, 12, 1527-1544. [CrossRef]

80. Du, J.; Zhu, Z.; Xu, L.; Chen, X.; Li, X.; Lan, T.; Li, W.; Yuan, K.; Zeng, Y. ARHGEF11 promotes proliferation and epithelialmesenchymal transition of hepatocellular carcinoma through activation of $\beta$-catenin pathway. Aging 2020, 12, 20235-20253. [CrossRef]

81. Song, M.; Pan, Q.; Yang, J.; He, J.; Zeng, J.; Cheng, S.; Huang, Y.; Zhou, Z.Q.; Zhu, Q.; Yang, C.; et al. Galectin-3 favours tumour metastasis via the activation of $\beta$-catenin signalling in hepatocellular carcinoma. Br. J. Cancer 2020, 123, 1521-1534. [CrossRef]

82. Wei, S.; Dai, M.; Zhang, C.; Teng, K.; Wang, F.; Li, H.; Sun, W.; Feng, Z.; Kang, T.; Guan, X.; et al. KIF2C: A novel link between Wnt/ $\beta$-catenin and mTORC1 signaling in the pathogenesis of hepatocellular carcinoma. Protein Cell 2020, 12, 788-809. [CrossRef] [PubMed]

83. Yang, B.; Wang, S.; Xie, H.; Wang, C.; Gao, X.; Rong, Y.; Liu, Z.; Lu, Y. KIF18B promotes hepatocellular carcinoma progression through activating Wnt/ $\beta$-catenin-signaling pathway. J. Cell. Physiol. 2020, 235, 6507-6514. [CrossRef] [PubMed]

84. Zhu, K.; Peng, Y.; Hu, J.; Zhan, H.; Yang, L.; Gao, Q.; Jia, H.; Luo, R.; Dai, Z.; Tang, Z.; et al. Metadherin-PRMT5 complex enhances the metastasis of hepatocellular carcinoma through the WNT-ß-catenin signaling pathway. Carcinogenesis 2020, 41, 130-138. [CrossRef] [PubMed]

85. Chen, J.; Wang, M.; Xiang, Y.; Ru, X.; Ren, Y.; Liu, X.; Qiu, L.; Zhang, Y. Nrf1 is endowed with a dominant tumor-repressing effect onto the Wnt / $\beta$-catenin-dependent and Wnt/ $\beta$-catenin-independent signaling networks in the human liver cancer. Oxid. Med. Cell. Longev. 2020, 2020, 5138539. [CrossRef]

86. Qianqian, L.I.; Ningbo, L.I.; Zeng, Y.; Wang, X.; Jie, L.I.; Hongying, S.U.; Meiqin, G.A.O.; Huang, X. Nuclear receptor FXR impairs SK-Hep-1 cell migration and invasion by inhibiting the Wnt/ $\beta$-catenin signaling pathway. Oncol. Lett. 2020, 20, 161. [CrossRef]

87. Li, Y.; Xu, Y.; Gao, C.; Sun, Y.; Zhou, K.; Wang, P.; Cheng, J.; Guo, W.; Ya, C.; Fan, J.; et al. USP1 Maintains the survival of liver circulating tumor cells by deubiquitinating and stabilizing TBLR1. Front. Oncol. 2020, 10, 554809. [CrossRef] 
88. Xu, C.; Li, Y.-M.; Sun, B.; Zhong, F.-J.; Yang, L.-Y. ATE1 Inhibits liver cancer progression through rgs5-mediated suppression of Wnt/ $\beta$-catenin signaling. Mol. Cancer Res. 2021, 19, 1441-1453. [CrossRef]

89. Zuo, Q.; He, J.; Zhang, S.; Wang, H.; Jin, G.; Jin, H.; Cheng, Z.; Tao, X.; Yu, C.; Li, B.; et al. PPAR $\gamma$ coactivator- $1 \alpha$ suppresses metastasis of hepatocellular carcinoma by inhibiting Warburg effect by PPAR $\gamma$-dependent WNT/ $\beta$-catenin/pyruvate dehydrogenase kinase isozyme 1 axis. Hepatology 2021, 73, 644-660. [CrossRef]

90. Feng, S.; Liu, J.; Hailiang, L.; Wen, J.; Zhao, Y.; Li, X.; Lu, G.; Gao, P.; Zeng, X. Amplification of RAD54B promotes progression of hepatocellular carcinoma via activating the Wnt/ $\beta$-catenin signaling. Transl. Oncol. 2021, 14, 101124. [CrossRef]

91. Li, L.Y.; Yang, J.F.; Rong, F.; Luo, Z.P.; Hu, S.; Fang, H.; Wu, Y.; Yao, R.; Kong, W.H.; Feng, X.W.; et al. ZEB1 serves an oncogenic role in the tumourigenesis of HCC by promoting cell proliferation, migration, and inhibiting apoptosis via Wnt/ $\beta$-catenin signaling pathway. Acta Pharmacol. Sin. 2021, 42, 1676-1689. [CrossRef]

92. Steinbichler, T.B.; Savic, D.; Dudás, J.; Kvitsaridze, I.; Skvortsov, S.; Riechelmann, H.; Skvortsova, I.I. Cancer stem cells and their unique role in metastatic spread. Semin. Cancer Biol. 2020, 60, 148-156. [CrossRef]

93. de Sousa e Melo, F.; Vermeulen, L. Wnt signaling in cancer stem cell biology. Cancers 2016, 8, 60. [CrossRef] [PubMed]

94. Kahn, M. Wnt signaling in stem cells and cancer stem cells: A tale of two coactivators. Prog. Mol. Biol. Transl. Sci. 2018, 153, 209-244. [CrossRef] [PubMed]

95. Chen, X.; Huan, H.; Liu, C.; Luo, Y.; Shen, J.; Zhuo, Y.; Zhang, Z.; Qian, C. Deacetylation of $\beta$-catenin by SIRT1 regulates self-renewal and oncogenesis of liver cancer stem cells. Cancer Lett. 2019, 463, 1-10. [CrossRef] [PubMed]

96. Kim, J.Y.; Lee, H.Y.; Park, K.K.; Choi, Y.K.; Nam, J.S.; Hong, I.S. CWP232228 targets liver cancer stem cells through Wnt/ $\beta$-catenin signaling: A novel therapeutic approach for liver cancer treatment. Oncotarget 2016, 7, 20395-20409. [CrossRef]

97. Leung, C.O.N.; Mak, W.N.; Kai, A.K.L.; Chan, K.S.; Lee, T.K.W.; Ng, I.O.L.; Lo, R.C.L. Sox9 confers stemness properties in hepatocellular carcinoma through Frizzled-7 mediated Wnt/ $\beta$-catenin signaling. Oncotarget 2016, 7, 29371-29386. [CrossRef]

98. Deng, Y.; Li, M.; Zhuo, M.; Guo, P.; Chen, Q.; Mo, P.; Li, W.; Yu, C. Histone demethylase JMJD2D promotes the self-renewal of liver cancer stem-like cells by enhancing EpCAM and Sox9 expression. J. Biol. Chem. 2021, 296, 100121. [CrossRef]

99. Lou, W.; Liu, J.; Gao, Y.; Zhong, G.; Ding, B.; Xu, L. MicroRNA regulation of liver cancer stem cells. Am. J. Cancer Res. 2018, 8, 1126-1141.

100. Tang, J.; Tao, Z.H.; Wen, D.; Wan, J.L.; Liu, D.L.; Zhang, S.; Cui, J.F.; Sun, H.C.; Wang, L.; Zhou, J.; et al. MiR-612 suppresses the stemness of liver cancer via Wnt/beta-catenin signaling. Biochem. Biophys. Res. Commun. 2014, 447, 210-215. [CrossRef]

101. Zheng, Z.; Liu, J.; Yang, Z.; Wu, L.; Xie, H.; Jiang, C.; Lin, B.; Chen, T.; Xing, C.; Liu, Z.; et al. MicroRNA-452 promotes stem-like cells of hepatocellular carcinoma by inhibiting sox7 involving wnt/ $\beta$-catenin signaling pathway. Oncotarget 2016, 7, 28000-28012 [CrossRef] [PubMed]

102. Lin, X.; Zuo, S.; Luo, R.; Li, Y.; Yu, G.; Zou, Y.; Zhou, Y.; Liu, Z.; Liu, Y.; Hu, Y.; et al. HBX-induced miR-5188 impairs FOXO1 to stimulate $\beta$-catenin nuclear translocation and promotes tumor stemness in hepatocellular carcinoma. Theranostics 2019, 9, 7583-7598. [CrossRef] [PubMed]

103. Fu, X.; Lin, J.; Qin, F.; Yang, Z.; Ding, Y.; Zhang, Y.; Han, L.; Zhu, X.; Zhang, Q. LncAPC drives Wnt/ $\beta$-catenin activation and liver TIC self-renewal through EZH2 mediated APC transcriptional inhibition. Mol. Carcinog. 2018, 57, 408-418. [CrossRef]

104. Li, X.; Li, M.; Chen, J.; Dai, H.; Wang, L.; Xiong, Y.; Zhong, Y.; Zhang, L. SAMMSON drives the self-renewal of liver tumor initiating cells through EZH2-dependent Wnt/ $\beta$-catenin activation. Oncotarget 2017, 8, 103785-103796. [CrossRef]

105. Chen, Z.; Gao, Y.; Yao, L.; Liu, Y.; Huang, L.; Yan, Z.; Zhao, W.; Zhu, P.; Weng, H. LncFZD6 initiates Wnt/ $\beta$-catenin and liver TIC self-renewal through BRG1-mediated FZD6 transcriptional activation. Oncogene 2018, 37, 3098-3112. [CrossRef]

106. Yan, X.; Zhang, D.; Wu, W.; Wu, S.; Qian, J.; Hao, Y.; Yan, F.; Zhu, P.; Wu, J.; Huang, G.; et al. Mesenchymal stem cells promote hepatocarcinogenesis via lncRNA-MUF interaction with ANXA2 and miR-34a. Cancer Res. 2017, 77, 6704-6716. [CrossRef]

107. Hou, J.; Zhao, N.; Zhu, P.; Chang, J.; Du, Y.; Shen, W. Irradiated mesenchymal stem cells support stemness maintenance of hepatocellular carcinoma stem cells through Wnt/ $\beta$-catenin signaling pathway. Cell Biosci. 2020, 10, 93. [CrossRef]

108. Wu, N.; Zhang, Y.L.; Wang, H.T.; Li, D.W.; Dai, H.J.; Zhang, Q.Q.; Zhang, J.; Ma, Y.; Xia, Q.; Bian, J.M.; et al. Overexpression of hepatocyte nuclear factor $4 \alpha$ in human mesenchymal stem cells suppresses hepatocellular carcinoma development through Wnt $/ \beta$-catenin signaling pathway downregulation. Cancer Biol. Ther. 2016, 17, 558-565. [CrossRef]

109. Yang, Y.; Ye, Y.C.; Chen, Y.; Zhao, J.L.; Gao, C.C.; Han, H.; Liu, W.C.; Qin, H.Y. Crosstalk between hepatic tumor cells and macrophages via Wnt/ $\beta$-catenin signaling promotes M2-like macrophage polarization and reinforces tumor malignant behaviors. Cell Death Dis. 2018, 9, 793. [CrossRef]

110. Tian, X.; Wu, Y.; Yang, Y.; Wang, J.; Niu, M.; Gao, S.; Qin, T.; Bao, D. Long noncoding RNA LINC00662 promotes M2 macrophage polarization and hepatocellular carcinoma progression via activating Wnt/ $\beta$-catenin signaling. Mol. Oncol. 2020, 14, 462-483. [CrossRef] [PubMed]

111. Huang, J.L.; Fu, Y.P.; Gan, W.; Liu, G.; Zhou, P.Y.; Zhou, C.; Sun, B.Y.; Guan, R.Y.; Zhou, J.; Fan, J.; et al. Hepatic stellate cells promote the progression of hepatocellular carcinoma through microRNA-1246-ROR $\alpha$-Wnt/ $\beta$-Catenin axis. Cancer Lett. 2020, 476, 140-151. [CrossRef]

112. Olsen, J.J.; Pohl, S.; Öther, G.; Deshmukh, A.; Visweswaran, M.; Ward, N.C.; Arfuso, F.; Agostino, M.; Dharmarajan, A. The role of Wnt signalling in angiogenesis. Clin. Biochem. Rev. 2017, 38, 131-142.

113. Samarzija, I.; Sini, P.; Schlange, T.; MacDonald, G.; Hynes, N.E. Wnt3a regulates proliferation and migration of HUVEC via canonical and non-canonical Wnt signaling pathways. Biochem. Biophys. Res. Commun. 2009, 386, 449-454. [CrossRef] [PubMed] 
114. Inverso, D.; Shi, J.; Lee, K.H.; Jakab, M.; Ben-Moshe, S.; Kulkarni, S.R.; Schneider, M.; Wang, G.; Komeili, M.; Vélez, P.A.; et al. A spatial vascular transcriptomic, proteomic, and phosphoproteomic atlas unveils an angiocrine Tie-Wnt signaling axis in the liver. Dev. Cell 2021, 56, 1677-1693. [CrossRef] [PubMed]

115. Leibing, T.; Géraud, C.; Augustin, I.; Boutros, M.; Augustin, H.G.; Okun, J.G.; Langhans, C.D.; Zierow, J.; Wohlfeil, S.A.; Olsavszky, V.; et al. Angiocrine Wnt signaling controls liver growth and metabolic maturation in mice. Hepatology 2018, 68, 707-722. [CrossRef] [PubMed]

116. Yang, C.; Xu, Y.; Cheng, F.; Hu, Y.; Yang, S.; Rao, J.; Wang, X. Mir-1301 inhibits hepatocellular carcinoma cell migration, invasion, and angiogenesis by decreasing wnt/ $\beta$-catenin signaling through targeting bcl9. Cell Death Dis. 2017, 8, e2999. [CrossRef] [PubMed]

117. Zhang, N.; Wang, L.; Chai, Z.T.; Zhu, Z.M.; Zhu, X.D.; Ma, D.N.; Zhang, Q.B.; Zhao, Y.M.; Wang, M.; Ao, J.Y.; et al. Incomplete radiofrequency ablation enhances invasiveness and metastasis of residual cancer of hepatocellular carcinoma cell HCCLM3 via activating $\beta$-catenin signaling. PLoS ONE 2014, 9, e115949. [CrossRef] [PubMed]

118. Zhang, N.; Li, H.; Qin, C.; Ma, D.; Zhao, Y.; Zhu, W.; Wang, L. Insufficient radiofrequency ablation promotes the metastasis of residual hepatocellular carcinoma cells via upregulating flotillin proteins. J. Cancer Res. Clin. Oncol. 2019, 145, 895-907. [CrossRef]

119. Schatoff, E.M.; Leach, B.I.; Dow, L.E. WNT Signaling and Colorectal Cancer. Curr. Colorectal Cancer Rep. 2017, 13, 101-110. [CrossRef]

120. Markowitz, S.D.; Bertagnolli, M.M. Molecular origins of cancer: Molecular basis of colorectal cancer. N. Engl. J. Med. 2009, 361, 2449-2460. [CrossRef]

121. Cheng, X.; Xu, X.; Chen, D.; Zhao, F.; Wang, W. Therapeutic potential of targeting the Wnt/ $\beta$-catenin signaling pathway in colorectal cancer. Biomed. Pharmacother. 2019, 110, 473-481. [CrossRef]

122. Zhu, G.X.; Gao, D.; Shao, Z.Z.; Chen, L.; Ding, W.J.; Yu, Q.F. Wnt/ $\beta$-catenin signaling: Causes and treatment targets of drug resistance in colorectal cancer (Review). Mol. Med. Rep. 2021, 23, 105. [CrossRef]

123. Katoh, M. WNT2 and human gastrointestinal cancer (review). Int. J. Mol. Med. 2003, 12, 811-816. [CrossRef]

124. Peng, J.; Zhao, Y.; Luo, Q.; Chen, H.; Fan, W.; Pan, Z.; Wang, X.; Zhang, L. High WNT6 expression indicates unfavorable survival outcome for patients with colorectal liver metastasis after liver resection. J. Cancer 2019, 10, 2619-2627. [CrossRef]

125. Suzuki, H.; Masuda, N.; Shimura, T.; Araki, K.; Kobayashi, T.; Tsutsumi, S.; Asao, T.; Kuwano, H. Nuclear $\beta$-catenin expression at the invasive front and in the vessels predicts liver metastasis in colorectal carcinoma. Anticancer Res. 2008, 28, 1821-1830.

126. Cheng, H.; Liang, H.; Qin, Y.; Liu, Y. Nuclear beta-catenin overexpression in metastatic sentinel lymph node is associated with synchronous liver metastasis in colorectal cancer. Diagn. Pathol. 2011, 6, 109. [CrossRef] [PubMed]

127. Michl, M.; Heinemann, V.; Jung, A.; Engel, J.; Kirchner, T.; Neumann, J. Expression of cancer stem cell markers in metastatic colorectal cancer correlates with liver metastasis, but not with metastasis to the central nervous system. Pathol. Res. Pract. 2015, 211, 601-609. [CrossRef] [PubMed]

128. Chang, J.Y.; Kim, J.H.; Kang, J.; Park, Y.; Park, S.J.; Cheon, J.H.; Kim, W.H.; Kim, H.; Park, J.J.; Kim, T. Il mTOR signaling combined with cancer stem cell markers as a survival predictor in stage II colorectal cancer. Yonsei Med. J. 2020, 61, 572-578. [CrossRef] [PubMed]

129. Au, K.Y.; Lo, R.C.L. An immunohistochemical study of $\beta$-catenin expression and immune cell population in metastatic carcinoma to the liver. Pathol. Oncol. Res. 2021, 27, 1609752. [CrossRef]

130. Kraus, S.; Vay, C.; Baldus, S.; Knoefel, W.T.; Stoecklein, N.H.; Vallbohmer, D. Expression of wingless-type mouse mammary tumor virus integration site family pathway effectors in lymphatic and hepatic metastases of patients with colorectal cancer: Associations with the primary tumor. Oncol. Lett. 2015, 10, 863-868. [CrossRef]

131. Kirana, C.; Smith, E.; Ngo, D.T.; Trochsler, M.I.; Hewett, P.J.; Stubbs, R.S.; Hardingham, J.E.; Maddern, G.J.; Hauben, E. High preoperative levels of circulating SFRP5 predict better prognosis in colorectal cancer patients. Futur. Oncol. 2020, 16, 2499-2509. [CrossRef]

132. Ueno, K.; Hazama, S.; Mitomori, S.; Nishioka, M.; Suehiro, Y.; Hirata, H.; Oka, M.; Imai, K.; Dahiya, R.; Hinoda, Y. Downregulation of frizzled-7 expression decreases survival, invasion and metastatic capabilities of colon cancer cells. Br. J. Cancer 2009, 101, 1374-1381. [CrossRef]

133. Qi, J.; Yu, Y.; Öztürk, Ö.A.; Holland, J.D.; Besser, D.; Fritzmann, J.; Wulf-Goldenberg, A.; Eckert, K.; Fichtner, I.; Birchmeier, W. New Wnt/ $\beta$-catenin target genes promote experimental metastasis and migration of colorectal cancer cells through different signals. Gut 2016, 65, 1690-1701. [CrossRef]

134. Li, Y.; Lv, Z.; He, G.; Wang, J.; Zhang, X.; Lu, G.; Ren, X.; Wang, F.; Zhu, X.; Ding, Y.; et al. The SOX17/miR-371-5p/SOX2 axis inhibits EMT, stem cell properties and metastasis in colorectal cancer. Oncotarget 2015, 6, 9099-9112. [CrossRef]

135. Liang, J.; Chen, M.; Hughes, D.; Chumanevich, A.A.; Altilia, S.; Kaza, V.; Lim, C.U.; Kiaris, H.; Mythreye, K.; Pena, M.M.; et al. CDK8 selectively promotes the growth of colon cancer metastases in the liver by regulating gene expression of TIMP3 and matrix metalloproteinases. Cancer Res. 2018, 78, 6594-6606. [CrossRef] [PubMed]

136. Cai, W.-S.; Shen, F.; Feng, Z.; Chen, J.-W.; Liu, Q.-C.; Li, E.-M.; Xu, B.; Cao, J. Downregulation of CDK-8 inhibits colon cancer hepatic metastasis by regulating Wnt/ $\beta$-catenin pathway. Biomed. Pharmacother. 2015, 74, 153-157. [CrossRef] [PubMed]

137. Yao, H.S.; Wang, J.; Zhang, X.P.; Wang, L.Z.; Wang, Y.; Li, X.X.; Jin, K.Z.; Hu, Z.Q.; Wang, W.J. Hepatocyte nuclear factor $4 \alpha$ suppresses the aggravation of colon carcinoma. Mol. Carcinog. 2016, 55, 458-472. [CrossRef] [PubMed] 
138. Chou, C.K.; Fan, C.C.; Lin, P.S.; Liao, P.Y.; Tung, J.C.; Hsieh, C.H.; Hung, M.C.; Chen, C.H.; Chang, W.C. Sciellin mediates mesenchymal-to-epithelial transition in colorectal cancer hepatic metastasis. Oncotarget 2016, 7, 25742-25754. [CrossRef]

139. Dong, X.; Liao, W.; Zhang, L.; Tu, X.; Hu, J.; Chen, T.; Dai, X.; Xiong, Y.; Liang, W.; Ding, C.; et al. RSPO2 suppresses colorectal cancer metastasis by counteracting the Wnt5a/Fzd7-driven noncanonical Wnt pathway. Cancer Lett. 2017, 402, 153-165. [CrossRef]

140. Li, S.; Han, Z.; Zhao, N.; Zhu, B.; Zhang, Q.; Yang, X.; Sheng, D.; Hou, J.; Guo, S.; Wei, L.; et al. Inhibition of DNMT suppresses the stemness of colorectal cancer cells through down-regulating Wnt signaling pathway. Cell. Signal. 2018, 47, 79-87. [CrossRef]

141. Zhao, H.; Zhao, C.; Li, H.; Zhang, D.; Liu, G. E2A attenuates tumor-initiating capacity of colorectal cancer cells via the Wnt/betacatenin pathway. J. Exp. Clin. Cancer Res. 2019, 38, 276. [CrossRef] [PubMed]

142. Chai, W.X.; Sun, L.G.; Dai, F.H.; Shao, H.S.; Zheng, N.G.; Cai, H.Y. Inhibition of PRRX2 suppressed colon cancer liver metastasis via inactivation of Wnt/ $\beta$-catenin signaling pathway. Pathol. Res. Pract. 2019, 215, 152593. [CrossRef]

143. Xu, C.; Tian, G.; Jiang, C.; Xue, H.; Kuerbanjiang, M.; Sun, L.; Gu, L.; Zhou, H.; Liu, Y.; Zhang, Z.; et al. NPTX2 promotes colorectal cancer growth and liver metastasis by the activation of the canonical Wnt/ $\beta$-catenin pathway via FZD6. Cell Death Dis. 2019, 10, 217. [CrossRef]

144. Wang, Z.; Zhang, J. FOXP3 promotes colorectal carcinoma liver metastases by evaluating MMP9 expression via regulating S-adenosylmethionine metabolism. Ann. Transl. Med. 2020, 8, 592. [CrossRef]

145. Tian, G.A.; Xu, C.J.; Zhou, K.X.; Zhang, Z.G.; Gu, J.R.; Zhang, X.L.; Wang, Y.H. MPC1 Deficiency Promotes CRC Liver Metastasis via Facilitating Nuclear Translocation of $\beta$-Catenin. J. Immunol. Res. 2020, 2020, 8340329. [CrossRef]

146. Agarwal, S.; Behring, M.; Kim, H.G.; Chandrashekar, D.S.; Chakravarthi, B.V.S.K.; Gupta, N.; Bajpai, P.; Elkholy, A.; Al Diffalha, S.; Datta, P.K.; et al. TRIP13 promotes metastasis of colorectal cancer regardless of p53 and microsatellite instability status. Mol. Oncol. 2020, 14, 3007-3029. [CrossRef]

147. Cheng, C.; Huang, Z.; Zhou, R.; An, H.; Cao, G.; Ye, J.; Huang, C.; Wu, D. Numb negatively regulates the epithelial-tomesenchymal transition in colorectal cancer through the Wnt signaling pathway. Am. J. Physiol.-Gastrointest. Liver Physiol. 2020, 318, G841-G853. [CrossRef] [PubMed]

148. Li, Y.J.; Yang, C.N.; Kuo, M.Y.P.; Lai, W.T.; Wu, T.S.; Lin, B.R. ATMIN Suppresses metastasis by altering the WNT-signaling pathway via PARP1 in MSI-high colorectal cancer. Ann. Surg. Oncol. 2021. [CrossRef]

149. Liu, Y.; Yue, M.; Li, Z. FOSL1 promotes tumorigenesis in colorectal carcinoma by mediating the FBXL2/Wnt/ $\beta$-catenin axis via Smurf1. Pharmacol. Res. 2021, 165, 105405. [CrossRef] [PubMed]

150. Song, Q.; Han, Z.; Wu, X.; Wang, Y.; Zhou, L.; Yang, L.; Liu, N.; Sui, H.; Cai, J.; Ji, Q.; et al. $\beta$-arrestin1 promotes colorectal cancer metastasis through GSK-3 $\beta / \beta$-catenin signaling- mediated epithelial-to-mesenchymal transition. Front. Cell Dev. Biol. 2021, 9 , 650067. [CrossRef]

151. Yin, H.; Gao, T.; Xie, J.; Huang, Z.; Zhang, X.; Yang, F.; Qi, W.; Yang, Z.; Zhou, T.; Gao, G.; et al. FUBP1 promotes colorectal cancer stemness and metastasis via DVL1-mediated activation of Wnt/ $\beta$-catenin signaling. Mol. Oncol. 2021. [CrossRef] [PubMed]

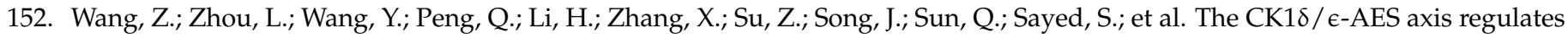
tumorigenesis and metastasis in colorectal cancer. Theranostics 2021, 11, 4421-4435. [CrossRef] [PubMed]

153. Sakai, E.; Nakayama, M.; Oshima, H.; Kouyama, Y.; Niida, A.; Fujii, S.; Ochiai, A.; Nakayama, K.I.; Mimori, K.; Suzuki, Y.; et al. Combined mutation of Apc, Kras, and Tgfbr2 effectively drives metastasis of intestinal cancer. Cancer Res. 2018, 78, 1334-1346. [CrossRef] [PubMed]

154. Feng, L.; Hong, S.; Gao, J.; Li, J. Whole-exome sequencing characterized the landscape of somatic mutations and pathways in colorectal cancer liver metastasis. J. Oncol. 2019, 2019, 2684075. [CrossRef] [PubMed]

155. Stein, U.; Arlt, F.; Smith, J.; Sack, U.; Herrmann, P.; Walther, W.; Lemm, M.; Fichtner, I.; Shoemaker, R.H.; Schlag, P.M. Intervening in $\beta$-catenin signaling by sulindac inhibits S100A4-dependent colon cancer metastasis. Neoplasia 2011, 13, 131-144. [CrossRef]

156. Sack, U.; Walther, W.; Scudiero, D.; Selby, M.; Kobelt, D.; Lemm, M.; Fichtner, I.; Schlag, P.M.; Shoemaker, R.H.; Stein, U. Novel effect of antihelminthic niclosamide on s100a4-mediated metastatic progression in colon cancer. J. Natl. Cancer Inst. 2011, 103, 1018-1036. [CrossRef]

157. Haase, G.; Gavert, N.; Brabletz, T.; Ben-Ze'ev, A. The wnt target gene L1 in colon cancer invasion and metastasis. Cancers 2016, 8 , 48. [CrossRef]

158. Gavert, N.; Vivanti, A.; Hazin, J.; Brabletz, T.; Ben-Ze'ev, A. L1-Mediated colon cancer cell metastasis does not require changes in EMT and cancer stem cell markers. Mol. Cancer Res. 2011, 9, 14-24. [CrossRef]

159. Wu, Z.; Wei, D.; Gao, W.; Xu, Y.; Hu, Z.; Ma, Z.; Gao, C.; Zhu, X.; Li, Q. TPO-Induced Metabolic Reprogramming Drives Liver Metastasis of Colorectal Cancer CD110+ Tumor-Initiating Cells. Cell Stem Cell 2015, 17, 47-59. [CrossRef]

160. Takahashi, H.; Ishii, H.; Nishida, N.; Takemasa, I.; Mizushima, T.; Ikeda, M.; Yokobori, T.; Mimori, K.; Yamamoto, H.; Sekimoto, M.; et al. Significance of Lgr5+ve cancer stem cells in the colon and rectum. Ann. Surg. Oncol. 2011, 18, 1166-1174. [CrossRef]

161. Xu, L.; Lin, W.; Wen, L.; Li, G. Lgr5 in cancer biology: Functional identification of Lgr5 in cancer progression and potential opportunities for novel therapy. Stem Cell Res. Ther. 2019, 10, 219. [CrossRef] [PubMed]

162. Hu, J.L.; Wang, W.; Lan, X.L.; Zeng, Z.C.; Liang, Y.S.; Yan, Y.R.; Song, F.Y.; Wang, F.F.; Zhu, X.H.; Liao, W.J.; et al. CAFs secreted exosomes promote metastasis and chemotherapy resistance by enhancing cell stemness and epithelial-mesenchymal transition in colorectal cancer. Mol. Cancer 2019. [CrossRef] 
163. Berdiel-Acer, M.; Bohem, M.E.; López-Doriga, A.; Vidal, A.; Salazar, R.; Martínez-Iniesta, M.; Santos, C.; Sanjuan, X.; Villanueva, A.; Molleví, D.G. Hepatic carcinoma-associated fibroblasts promote an adaptative response in colorectal cancer cells that inhibit proliferation and apoptosis: Nonresistant cells die by nonapoptotic cell death. Neoplasia 2011, 18, 91. [CrossRef]

164. Yang, M.; Wei, Z.; Feng, M.; Zhu, Y.; Chen, Y.; Zhu, D. Pharmacological inhibition and genetic knockdown of BCL9 modulate the cellular landscape of cancer-associated fibroblasts in the tumor-immune microenvironment of colorectal cancer. Front. Oncol. 2021, 11, 603556. [CrossRef]

165. Unterleuthner, D.; Neuhold, P.; Schwarz, K.; Janker, L.; Neuditschko, B.; Nivarthi, H.; Crncec, I.; Kramer, N.; Unger, C.; Hengstschläger, M.; et al. Cancer-associated fibroblast-derived WNT2 increases tumor angiogenesis in colon cancer. Angiogenesis 2020, 23, 159-177. [CrossRef]

166. Song, J.; Shu, H.; Zhang, L.; Xiong, J. Long noncoding RNA GAS5 inhibits angiogenesis and metastasis of colorectal cancer through the Wnt/ $\beta$-catenin signaling pathway. J. Cell. Biochem. 2019, 120, 6937-6951. [CrossRef]

167. Kasprzak, A. Angiogenesis-related functions of wnt signaling in colorectal carcinogenesis. Cancers 2020, 12, 3601. [CrossRef]

168. Zhang, Y.; Song, J.; Zhao, Z.; Yang, M.; Chen, M.; Liu, C.; Ji, J.; Zhu, D. Single-cell transcriptome analysis reveals tumor immune microenvironment heterogenicity and granulocytes enrichment in colorectal cancer liver metastases. Cancer Lett. 2020, 470, 84-94. [CrossRef]

169. Park, J.; Schlederer, M.; Schreiber, M.; Ice, R.; Merkel, O.; Bilban, M.; Hofbauer, S.; Kim, S.; Addison, J.; Zou, J.; et al. AF1q is a novel TCF7 co-factor which activates CD44 and promotes breast cancer metastasis. Oncotarget 2015, 6, 20697-20710. [CrossRef]

170. Corda, G.; Sala, G.; Lattanzio, R.; Iezzi, M.; Sallese, M.; Fragassi, G.; Lamolinara, A.; Mirza, H.; Barcaroli, D.; Ermler, S.; et al. Functional and prognostic significance of the genomic amplification of frizzled 6 (FZD6) in breast cancer. J. Pathol. 2017, 241, 350-361. [CrossRef] [PubMed]

171. Bleckmann, A.; Conradi, L.C.; Menck, K.; Schmick, N.A.; Schubert, A.; Rietkötter, E.; Arackal, J.; Middel, P.; Schambony, A.; Liersch, T.; et al. $\beta$-catenin-independent WNT signaling and Ki67 in contrast to the estrogen receptor status are prognostic and associated with poor prognosis in breast cancer liver metastases. Clin. Exp. Metastasis 2016, 33, 309-323. [CrossRef]

172. Fatima, I.; El-Ayachi, I.; Playa, H.C.; Alva-Ornelas, J.A.; Khalid, A.B.; Kuenzinger, W.L.; Wend, P.; Pence, J.C.; Brakefield, L.; Krutilina, R.I.; et al. Simultaneous multi-organ metastases from chemo-resistant triple-negative breast cancer are prevented by interfering with WNT-signaling. Cancers 2019, 11, 2039. [CrossRef] [PubMed]

173. Ebert, M.P.A.; Yu, J.; Hoffmann, J.; Rocco, A.; Röcken, C.; Kahmann, S.; Müller, O.; Korc, M.; Sung, J.J.; Malfertheiner, P. Loss of beta-catenin expression in metastatic gastric cancer. J. Clin. Oncol. 2003, 21, 1708-1714. [CrossRef] [PubMed]

174. Luo, G.Q.; Li, J.H.; Wen, J.F.; Zhou, Y.H.; Hu, Y.B.; Zhou, J.H. Effect and mechanism of the Twist gene on invasion and metastasis of gastric carcinoma cells. World J. Gastroenterol. 2008, 14, 2487-2493. [CrossRef] [PubMed]

175. Hanaki, H.; Yamamoto, H.; Sakane, H.; Matsumoto, S.; Ohdan, H.; Sato, A.; Kikuchi, A. An anti-Wnt5a antibody suppresses metastasis of gastric cancer cells in vivo by inhibiting receptor-mediated endocytosis. Mol. Cancer Ther. 2012, 11, $298-307$. [CrossRef] [PubMed]

176. Fu, Y.; Chen, Y.; Huang, J.; Cai, Z.; Wang, Y. RYK, a receptor of noncanonical Wnt ligand Wnt5a, is positively correlated with gastric cancer tumorigenesis and potential of liver metastasis. Am. J. Physiol.-Gastrointest. Liver Physiol. 2020, 318, G352-G360. [CrossRef] [PubMed]

177. Ara, H.; Takagishi, M.; Enomoto, A.; Asai, M.; Ushida, K.; Asai, N.; Shimoyama, Y.; Kaibuchi, K.; Kodera, Y.; Takahashi, M. Role for Daple in non-canonical Wnt signaling during gastric cancer invasion and metastasis. Cancer Sci. 2016, 107, 133-139. [CrossRef]

178. Wang, S.; Qiu, M.; Xia, W.; Xu, Y.; Mao, Q.; Wang, J.; Dong, G.; Xu, L.; Yang, X.; Yin, R. Glypican-5 suppresses epithelialmesenchymal transition of the lung adenocarcinoma by competitively binding to Wnt3a. Oncotarget 2016, 7, 79736-79746. [CrossRef]

179. Wang, B.; Tang, Z.; Gong, H.; Zhu, L.; Liu, X. Wnt5a promotes epithelial-to-mesenchymal transition and metastasis in non-smallcell lung cancer. Biosci. Rep. 2017, 37, BSR20171092. [CrossRef]

180. Zhang, H.J.; Chang, W.J.; Jia, C.Y.; Qiao, L.; Zhou, J.; Chen, Q.; Zheng, X.W.; Zhang, J.H.; Li, H.C.; Yang, Z.Y.; et al. Destrin contributes to lung adenocarcinoma progression by activating Wnt/ $\beta$-catenin signaling pathway. Mol. Cancer Res. 2020, 18, 1789-1802. [CrossRef]

181. Sinnberg, T.; Levesque, M.P.; Krochmann, J.; Cheng, P.F.; Ikenberg, K.; Meraz-Torres, F.; Niessner, H.; Garbe, C.; Busch, C. Wnt-signaling enhances neural crest migration of melanoma cells and induces an invasive phenotype. Mol. Cancer $2018,17,59$. [CrossRef]

182. Chetty, R.; Serra, S.; Asa, S.L. Loss of membrane localization and aberrant nuclear E-cadherin expression correlates with invasion in pancreatic endocrine tumors. Am. J. Surg. Pathol. 2008, 32, 413-419. [CrossRef]

183. Sannino, G.; Armbruster, N.; Bodenhöfer, M.; Haerle, U.; Behrens, D.; Buchholz, M.; Rothbauer, U.; Sipos, B.; Schmees, C. Role of BCL9L in transforming growth factor- $\beta$ (TGF- $\beta$ )-induced epithelial-to-mesenchymal-transition (EMT) and metastasis of pancreatic cancer. Oncotarget 2016, 7, 73725-73738. [CrossRef]

184. Saxena, S.; Purohit, A.; Varney, M.L.; Hayashi, Y.; Singh, R.K. Semaphorin-5A maintains epithelial phenotype of malignant pancreatic cancer cells. BMC Cancer 2018, 18, 1283. [CrossRef]

185. Yang, J.; Ye, Z.; Mei, D.; Gu, H.; Zhang, J. Long noncoding RNA DLX6-AS1 promotes tumorigenesis by modulating miR-4975p/FZD4/ FZD6/Wnt/ $\beta$-catenin pathway in pancreatic cancer. Cancer Manag. Res. 2019, 11, 4209-4221. [CrossRef] 
186. Han, Y.; Ru, G.Q.; Mou, X.; Wang, H.J.; Ma, Y.; He, X.L.; Yan, Z.; Huang, D. AUTS2 is a potential therapeutic target for pancreatic cancer patients with liver metastases. Med. Hypotheses 2015, 85, 203-206. [CrossRef]

187. Xu, D.; Yuan, H.; Meng, Z.; Yang, C.; Li, Z.; Li, M.; Zhang, Z.; Gan, Y.; Tu, H. Cadherin 13 inhibits pancreatic cancer progression and epithelial-mesenchymal transition by Wnt/ $\beta$-catenin signaling. J. Cancer 2020, 11, 2101-2112. [CrossRef]

188. Chen, T.; Lei, S.; Zeng, Z.; Zhang, J.; Xue, Y.; Sun, Y.; Lan, J.; Xu, S.; Mao, D.; Guo, B. Linc00261 inhibits metastasis and the WNT signaling pathway of pancreatic cancer by regulating a miR-552-5p/FOXO3 axis. Oncol. Rep. 2020, 43, 930-942. [CrossRef] [PubMed]

189. Samaržija, I. Site-specific and common prostate cancer metastasis genes as suggested by meta-analysis of gene expression data. Life 2021, 11, 636. [CrossRef] [PubMed]

190. Hall, C.L.; Daignault, S.D.; Shah, R.B.; Pienta, K.J.; Keller, E.T. Dickkopf-1 expression increases early in prostate cancer development and decreases during progression from primary tumor to metastasis. Prostate 2008, 68, 1396-1404. [CrossRef] [PubMed]

191. Lu, Z.H.; Kaliberov, S.; Sohn, R.E.; Kaliberova, L.; Du, Y.; Prior, J.L.; Leib, D.J.; Chauchereau, A.; Sehn, J.K.; Curiel, D.T.; et al. A new model of multi-visceral and bone metastatic prostate cancer with perivascular niche targeting by a novel endothelial specific adenoviral vector. Oncotarget 2017, 8, 12272-12289. [CrossRef] [PubMed] 